\title{
How a Country Can Reach the Top World Shipping Position by Creating Leading Companies? The Late John Angelicoussis Case Study
}

\author{
Alexandros M. Goulielmos' ${ }^{1,2}$ \\ ${ }^{1}$ Department of Maritime Studies, Faculty of Maritime and Industrial Studies, University of Piraeus, Piraeus, Greece \\ ${ }^{2}$ Shipping, Transport and Logistics Department, Business College of Athens, Athens, Greece \\ Email: ag@unipi.gr,am.goulielmos@hotmail.com, agoulielmos@bca.edu.gr
}

How to cite this paper: Goulielmos, A. M. (2021). How a Country Can Reach the Top World Shipping Position by Creating Leading Companies? The Late John Angelicoussis Case Study. Modern Economy, 12, 1004-1034. https://doi.org/10.4236/me.2021.125052

Received: April 7, 2021

Accepted: May 24, 2021

Published: May 27, 2021

Copyright $\odot 2021$ by author(s) and Scientific Research Publishing Inc. This work is licensed under the Creative Commons Attribution International License (CC BY 4.0).

http://creativecommons.org/licenses/by/4.0/

\begin{abstract}
The number of Greek-owned shipping companies achieved a fast growth starting from 256 shipping companies in 1914, 600 by 2017 (within the Greek borders only), and 1057 in 1990 . The number of shipping companies and the ships they own (dwt), finally determine the Greek owned fleet. This fleet owns $350.5 \mathrm{~m}$ dwt in 2021 (early). Greeks having ship-owning and ship-management in their tradition, and as a way of life, taught carefully these two concepts within their families. Shipowners-fathers cared for their children endowing them with a number of ships, including know-how. The way ship-owning families increased their size, the same way family members found their way towards creating their own, more powerful, shipping company! Moreover, a decade, or so, ago, we considered shipping industry as one dominated exclusively by men, but this is not true anymore. Angeliki Frangou and Anna Angelicoussis are two leading shipping married women, managing both $\sim 27 \mathrm{~m}$ dwt. By 2016 we counted 77 leading Greek-owned shipping companies owning/managing almost $300 \mathrm{~m}$ dwt (93.5\% of total Greek-owned fleet of $321 \mathrm{~m} \mathrm{dwt}$ ). Thus, the main suggestion for Nations wanting to excel in shipping is: "Create ship-owning families"! Leaders we consider those owning $\geq 1 \mathrm{~m} \mathrm{dwt} \mathrm{each}$.
\end{abstract}

\section{Keywords}

The Role of Ship-Owning Families in Greek-Owned Shipping Industry, 1970-2016 the Number and the Capacity (dwt) of Greek-Owned Shipping Companies, 1970-2016 the Greek Way to Become Champion in World 
Shipping Industry

\section{Introduction}

Greek $^{1}$ shipowners pursued all along a specific growth strategy and this way they arrived at top world positions, not only in the distant past, but also in 2021, in a continuous manner for longer than 7 decades (Figure 1).

The Greek-owned fleet increased from $170 \mathrm{~m}$ dwt (in mid-2007), to $349 \mathrm{~m}$ dwt (in mid-2018), a double figure in 11 years, owning 4536 ships $^{2}$ (av. size $100,000 \mathrm{dwt}$ ) and an almost $18 \%$ share in global fleet. The growth was fast, especially since mid-2009. A stagnation period, however, of 2 years occurred, due to Global Financial Crisis-GFC in end-2008, i.e., from mid-2007 to mid-2009.

The Greek-owned fleet operated 32\% tankers, and 23\% bulk carriers. Interesting is that $30 \%$ of Greek-owned ships were "gas carriers", carrying LNG, of which $15 \%$ concerned chemical products. Greek shipowners entered into the ownership of LNG ships in 2004 for the first time (Figure 2).

Greek $^{3}$ LNG fleet appeared in 2004, and doubled from 24 units (2012) to 48 (2014), and it is going to reach 104 ships by 2021 (by 28 on order). This indicates the global decisions to use less fossil fuels. Nowadays, due to the climatic collapse, there is a global and European turn, more decisive than hitherto towards

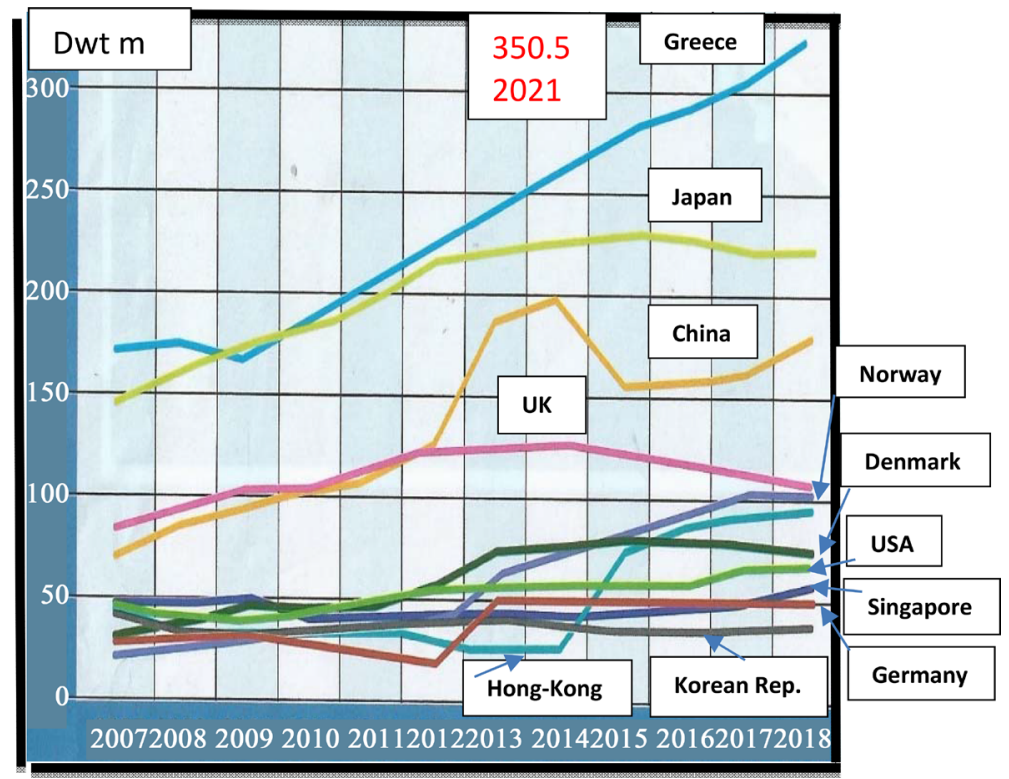

Source: UNCTAD, HIS Markit annual report; modified.

Figure 1. The top 11 global maritime nations, 2018.

\footnotetext{
${ }^{1}$ Under Greek and other 50 or so flags.

${ }^{2}$ The Pandemic affected Greek-owned fleet: in early 2021 it had 4038 ships and $350.5 \mathrm{~m}$ dwt. In 2020 the vessels were 3968 and the fleet $341 \mathrm{~m}$ dwt.

${ }^{3}$ Protagonists were: Minerva, a spin of Thenamaris; Anna Angelicoussis (3 ships), a spin of A Angelicoussis family; Cardiff (10); Tsakos; Angelicoussis John (35 units), a spin of A Angelicoussis family; Livanos Peter (30); Onassis; Dynagas (Procopiou G) and Chandris.
} 


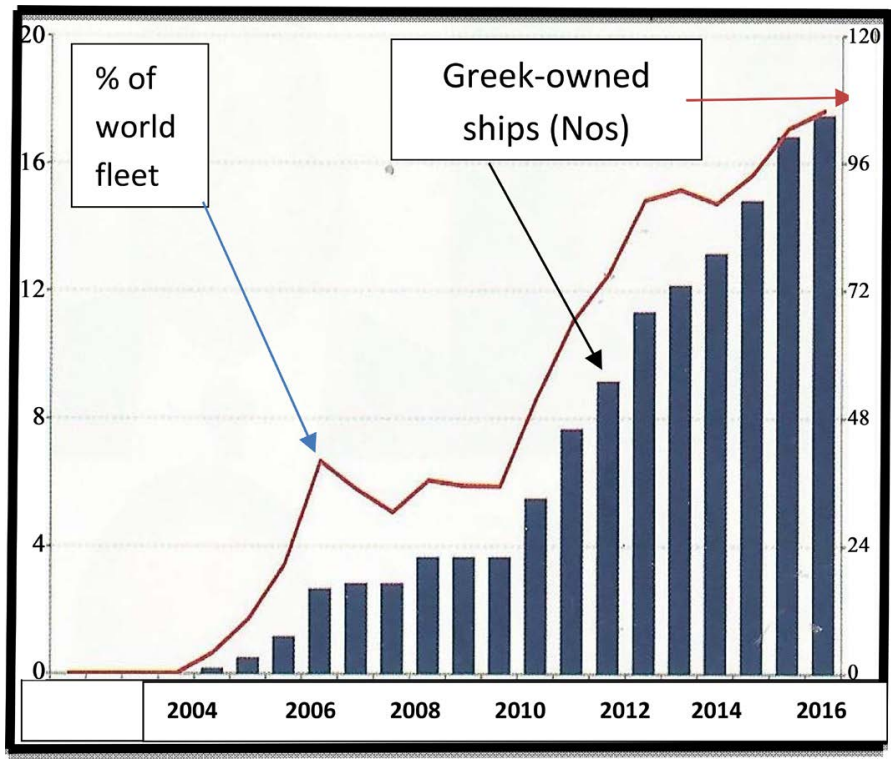

Source: The Intelligence, Lloyd's list, 2018, modified.

Figure 2. The Greek-owned LNG fleet, 2004-2021.

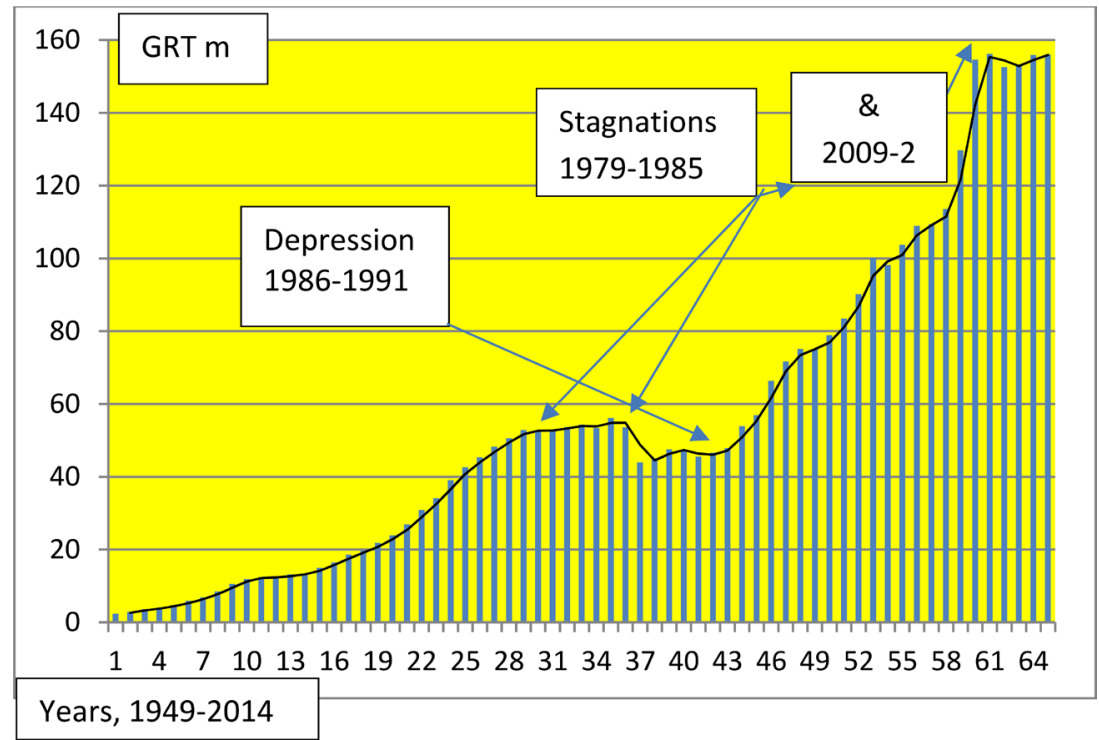

Source: Author; data from "Naftika Chronica" journal.

Figure 3. The growth of the Greek-owned fleet, 1949-2014.

the use of non-polluting fuels.

Nowadays, all shipping nations suffer from the repercussions of COVID-19, but while this may be a temporary, or short term, problem, there is the long-term transition into a state of zero pollution. The emissions of $\mathrm{CO}^{2}$ e.g., have to be reduced by $50 \%$ by 2050 , and this is a long-run challenge (IMO-International Maritime Organization-IMO.org.) (Goulielmos, 2020a).

The Greek-owned shipping though grew fast since 1949, halted during 1979-1985 (Figure 3), though a slow upward trend appeared. The 1986-1991 depression in tankers and in dry cargo ships, influenced it, as well GFC in end-2008, as men- 
tioned. Pandemic also stalled Greek-owned fleet in 2020-2021 (March)!

As shown, the Greek-owned fleet, increased from 2.38 m GRT (1949) to 156 $\mathrm{m}$ GRT in 2014 ( 291 $\mathrm{m} \mathrm{dwt})$. The growth over the last almost 20 years is shown next (Figure 4).

As shown, years 2008-13 indicate the halt of the growth of the Greek-owned fleet due to the global finance crisis in end-2008. The same occurred in 2019-2021 due to COVID-19. Despite these two adverse periods, the Greek-owned fleet over-doubled since 2002 and till 2021, from $165 \mathrm{~m}$ dwt to $350.5 \mathrm{~m}$. The growth was par excellence fast-due to favorable market conditions at that period of 2002-2008. From $165 \mathrm{~m}$ dwt it reached $261 \mathrm{~m}, 1.58$ times in just 8 years. Our predictions are that this fleet will increase fast in the next 10 years, if Pandemic passes-away till end 2021. It is clear to us that China and Greece will alternate in the top 2 world positions. China e.g., from $70 \mathrm{~m} \mathrm{dwt}$ in 2007 reached $200 \mathrm{~m}$ in 2014 to retreat to 175 in 2018 according to Figure 1. It is also possible that the growth of the pioneering fleets to be faster to gain the lost ground provided the Pandemic did not eliminate profits saved.

\section{Aim and Organization of the Paper}

The aim of the paper is to relate the growth of the Greek-owned shipping, from 1970 to 2021 (50 or so years), to the growth of Greek-owned shipping companies. These companies grew in number and in power (dwt). We showed how this took place. This is a lesson of particular interest to future managers! Equally important is that in order to have shipping companies, a nation must have managers. We showed also how shipping managers can be created. In order to

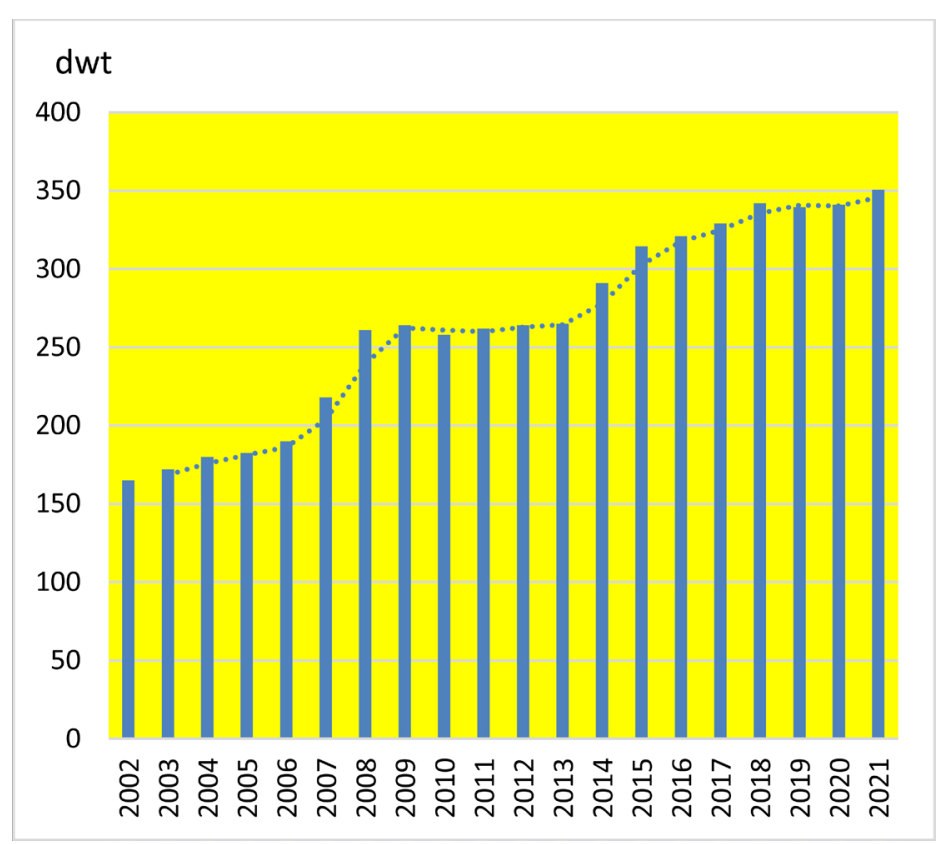

Source: "Greek shipping co-operation committee", London, annual, ships $>1000$ GRT in $1^{\text {st }}$ half of each year.

Figure 4. Greek-owned fleet, 2002-2021. 
have managers, however, a nation has to have ship owning families...

The paper is organized in 8 parts: Part I dealt with the conditions in the international and Greek-owned Shipping Industry ${ }^{4}$, 1979-1985; part II dealt with the legal framework prepared to repatriate Greek-owned (foreign) shipping companies, 1953-1994; part III dealt with the creation of the 19 leading Greek-owned shipping companies, 1970-1985; part IV dealt with the survival of Greek-owned companies from the 1981-1987 deep and prolonged depression; part V covered the 1993-1995 period; part VI dealt with year 2004; part VII dealt with the 2009-2016 period; part VIII dealt with the Angelicoussis A ship-owning family (a case-study). Finally, we concluded.

\section{Literature Review}

Stopford (2009: pp. 84, 324), in describing Greek shipowners, forgot what Keynes (1936) wrote, indirectly, about ... them (p. 150). Their job is a way of life, and not a profession, and certain countries-like Greece-have this in their tradition $^{5}$. For Stopford, shipping companies are very similar to the perfect competitive firms of the classical economists. Wrong, we reckon! We found out that the supply for ship services can be influenced by one big charterer, and more so by a number of big charterers (e.g., the 7 oil sisters); the supply of ship services, when massive, can also affect supply and thus freight rates (cases: San$\mathrm{ko}^{6}$; Eletson). Managers should have this possibility in mind.

For Stopford, a (shipping) company is a technical unit which hires transport services to those having to transport their produced goods from port of production to port of consumption. The shipowner is also the manager, and he/she decides what type, age and size etc. of a vessel to buy or build, judging mainly by her price vis-à-vis her freight rate. The sad fact is that, among shipowners, "the right hand does not know what the left one does", and thus many may build ships, which may not be needed...

In 2004, Stopford (p. 84) counted 5518 deep sea shipping companies owning 36,903 ships or 7 units per company (globally). The majority of companies (37\%) owned from 10 to 49 ships, while about 4000 owned $<5$. So, the majority (72.5\%) are small companies.

Stopford (2009) argued that "a Greek shipowner forms a private company to run a small tight organization under his control, making all decisions personally... He is concerned, rather exclusively, with the sale and purchase of ships, and whether to tie them on long-time charters or not". Surely, Greeks prefer personal, or family management, and ownership, and dislike Stock Exchanges (Goulielmos, 2021), but the size of their companies are not anymore small. Late Angelicoussis J, e.g., owned about $25 \mathrm{~m}$ dwt in 2018 ( $2^{\text {nd }}$ quarter).

\footnotetext{
${ }^{4}$ Ships owned by Greeks by majority $(50 \%+)$.

${ }^{5}$ Couper et al. (1999) and Harlaftis (1996) defined Greek traditional shipowners as those who-after $2^{\text {nd }} \mathrm{WW}-$ were shipowners during at least two generations.

${ }^{6}$ Sanko ordered $3-4 \mathrm{~m}$ dwt of dry cargoes in 1980s so that it reduced the prevailing freight rate...

(Stopford, 2009: p. 126; Couper et al., 1999: pp. 37-38).
} 
The literature about "the theory of the firm" is disappointing: Archibald (1971) wrote: "the theory of the firm is neither obvious nor explained" (p. 9)... Scientists spent much effort to establish firm's objective. And the common answer was that a firm "maximizes profits"; more clearly, it tries to widen the gap between total revenue and total cost. Max. Profits $=\max .(\mathrm{TR}-\mathrm{TC})\{1\}$, where TR is total revenue and TC is total cost. As this is a geometrical problem, we know that equation $\{1\}$ is fulfilled, when MC (marginal cost) $=$ MR (marginal revenue) $\{2\}$. Equation $\{2\}$ can also be written ${ }^{7}: M C=$ Freight rate $(F R)(1-1 / e)$ $\{6\}$, where e stands for elasticity of demand ${ }^{8}$.

Besanko et al. (2013: p. 27) called equation \{6\} a managerial way to use $M R$. Let company's total average variable cost be AVC, then the contribution (Cont.) of the freight rate to company's profits, is given by: Cont. $=($ FR-AVC $) /(\mathrm{FR})\{7\}$. This indicates that if a shipping company faces a freight rate $\mathrm{FR}$, and if e $>$ $1 /(\mathrm{FR}-\mathrm{AVC}) /(\mathrm{FR})\{8\}$, then company has to lower AVC in order to be profitable. Firms can know their marginal cost, only at equilibrium, as there: $\mathrm{MC}=\mathrm{AC}^{9}$ !

The matter we do not like in the above approach of economists is that the reader takes $\{1\}$ as achievable, and not as an effort. In a shipping firm we know that freight rate is determined by Supply and Demand, and firm tries always to achieve TC $<$ TR $\{9\}$. If a shipping company cannot make TC $<$ TR, then the unit (ship) closes up for a time, till TC $<$ TR. If this continues for say a long time (3 years or over), the unit is sold or scrapped.

Thus, for a shipping firm we have to define its objective as that of determining firm's total cost so that to be below prevailing total revenue ( $\mathrm{Q} \times \mathrm{FR}=\mathrm{TR}\{10\})$, constantly. This is known as a "constrained minimization of total cost, given price exogenously determined". Moreover, a shipping company is a multi-plant firm as ships normally are many in a company. Profit maximization requires then $\mathrm{MCi}=\operatorname{MRi}\{11\}$ by all units (where $i=1,2,3, \cdots, n$ ).

Couper et al. (1999: pp. 62-63) described Greek shipowners ${ }^{10}$ as many being ex-sea captains. In the past, Greeks owned 1 ship, sailed in command to gain capital, trading reliability and creditworthiness. Then they came ashore and developed their companies with an eye at the $2^{\text {nd }}$ hand markets. Small companies were created and run by only 1 man.

There were intermarriages between families of company owners, something happening till this day. Offices were staffed by relatives, retaining close business

\footnotetext{
${ }^{7}$ Proof: the elasticity of demand is by definition: $\mathrm{e}=-\mathrm{p} / \mathrm{q} \mathrm{dq} / \mathrm{dp}\{3\}$ and $\mathrm{MR}=\mathrm{p}+\mathrm{q} \mathrm{dp} / \mathrm{dq}\{4\}$ as the derivative of TR; putting $\{3\}$ into $\{4\}$, we derive: $M R=p(1-1 / e)\{5\}$ (Henderson \& Quandt, 1958: p. 168).

${ }^{8}$ An invention of Alfred Marshall.

${ }^{9}$ Let a freight rate be $\$ 10$ per dwt and firm's AVC $=\$ 5$ per dwt. Thus, the Cont. is $\$ 0.50$ (to profits). Profits then may increase if AVC is lowered, but this is possible only if e $>2(1 / 0.5)$.

${ }^{10}$ Changes in Greek crew structures occurred: first argument was that Greek labor force, out of only $6 \mathrm{~m}$ people then, cannot serve a shipping climbed-up at the top global positions. The $2^{\text {nd }}$ argument was that many competitive maritime nations used non-nationals, even most of EU members-including Norway-after 1986 (in dual registries). Thus, Greek shipowners tried to reduce nationals on board by reducing the number of ratings first. The third argument, which was similar to the first, was that national officers were fewer than needed, let alone their quality.
} 
and family links. They used to contribute cash as shareholders, and seafarers did the same (mutual dependence). The State allowed ${ }^{11}$, in 2000s, Greek shipowners to have on board 6 nationals, out of a maximum number of say 16, no matter their rank, except for the Captain. In our opinion this deprived shipping from shipowners coming from six ex-sea officers. These new crew teams, however, liked by Greek shipowners.

Couper et al. (1999)-based mainly on one Greek maritime historian (Harlaftis, 1996) - singled-out 6 features of growth and success of the modern Greek shipping industry (Graph 1).

Greeks admit that, after all, they have only two, as they call them, heavy industries: Tourism and Shipping, forgetting that God gave them "brain-B" to compensate them from a lack of natural resources (coal, oil, iron ore-except lignite)! He gave them also Sea, Sun and Sand. Greeks... do not use B, however, except if they work abroad...

Tenold (2015) argued that the success of a shipping company depends on some seemingly unrelated factors: analytical skills, hard work, and luck. Worth noting is that not all Greek-owned shipping companies were lucky. But their failures had a common cause: "they attempted a very rapid tonnage expansion, out of safe limits, helped by abundant finance provided by inexperienced banks...or even insurance companies"!

"Adriatic Tankers" ${ }^{12 " ~(P a n . ~ Z i s s i m a t o s) ~ e . g ., ~ c a u s e d ~ a ~ d i s a s t e r ~(S t o k e s, ~ 1997: ~ p p . ~}$ 113-115). It, till early 1990s, was successful dealing with up to 40 chemical and crude oil tankers. In 1992 its manager decided to expand to 100 vessels fast! And

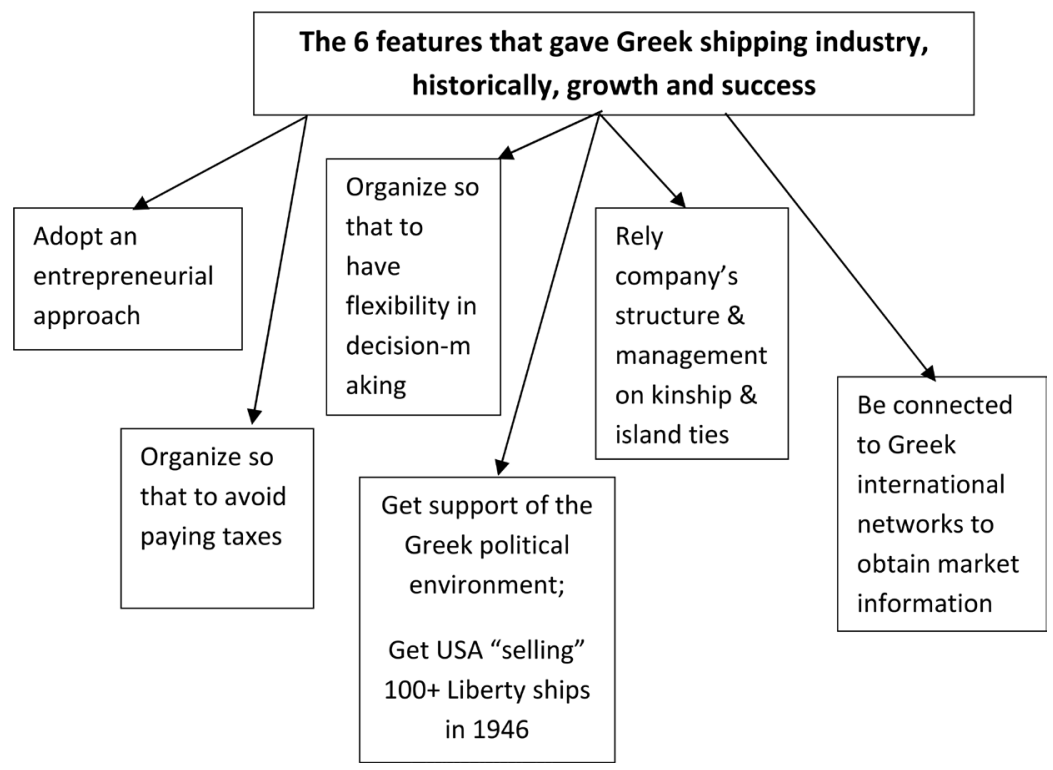

Source: Inspired by Couper et al., 1999: p. 63.

Graph 1. The 6 features that gave Greek shipping industry, historically, growth and success.

${ }^{11}$ E.g., a ship of 84,000 GT employs 16 persons, if automated. From these, 6 only are Greeks, including Captain. From end 2006, from having in crew 7 Greek officers, we have 5 + Captain nationals no matter their rank.

${ }^{12}$ A private Greek shipping group headed by Panagis Zissimatos. 
this regardless if freight rates would support company's cash flow, or if ships' off-hire would increase... The amount needed ( $\$ 240 \mathrm{~m}$, to repay it in 10 years) it was derived from the US bond market over a private placement based only on ships' evaluations. In 1995, the company collapsed, mainly due to not paying crew, bunkers suppliers and ship chandlers; involved was also ITWF (the sea labor union).

Lelakis A, experienced also the collapse of "Regency Cruises" in 1980-1990. This made Stokes (1997) to copy what "Savile G-Marquese of Halifax"-said: "the best way to suppose what may come, is to remember what is passed".

Amanatides acquired the "Tidal Marine" in 1966 and turned it into a fast-growing shipping company by 1969, buying 3 ships. An IPO in 1970 provided additional 10 ships in 12 months. In 1972, the company owned 45 ships (0.70 m dwt). Company's budget exploded in 1972, due to a severe cash flow crisis, helped by the 1971-1972 slump.

"Hellenic lines" (Callimanopulos) embarked on a $\$ 320 \mathrm{~m}$ containership program, in early 1980s, to serve Middle East, but this was not possible by 1983. An unfriendly bank (and leader, who put $\$ 80 \mathrm{~m}$ ) arrested a number of company's ships ${ }^{13}$.

Drawing the main conclusion from the above, in shipping business, frequently, we say: "Sky is the limit" ... but for a tentative fall from up there, one needs counter-means to avoid catastrophe.

\section{Part I: The Conditions in the International \& Greek-Owned Shipping Industry, 1979-1985}

There was a temporary market improvement in 1979-1980. The previous boom in dry cargoes reversed (March 1981). The Panamax vessel had an income of $\$ 5500 /$ day less in 11 months, out of $\$ 14,000$ she earned before; and in 1982 she lost a further $\$ 4200 /$ day. Figure 5 presents the world fleet in lay-up ${ }^{14}$ (unemployed).

As shown, in 1982 the world laid-up fleet was $85 \mathrm{~m}$ dwt (top; about $16 \%$ of World fleet). The situation improved after 1987, showing then $18 \mathrm{~m}$ dwt laid-up ( $\sim \%$ of World fleet). It seems that $5 \mathrm{~m} \mathrm{dwt}$ was a minimum for that period (1\% of global fleet) to be a normal lay-up amount.

Table 1 summarizes the condition in various freight markets between 1982 and 1987.

The majority of shipping markets (6/8) had several synchronized lows in summer 1986. Coal declined 2 times: in 1986 \& 1987. Tankers, and especially the big ones (250,000 dwt each), declined earlier: in 1985 (July). The exception is the tramp sector (time charter index) with a low in July-October 1982 (and in April 1986). Perhaps this index pre-told what was about to follow 4 years later! Apparently, tankers started to suffer first, perhaps 1 year before dry cargo ships.

${ }^{13}$ This case tells us that the choice of a banker has to be made very careful so that bankers to support a shipowner especially at the low phase of the cycle.

${ }^{14}$ Laid-up tonnage is a main indicator of how much profit can be derived from freight markets. 


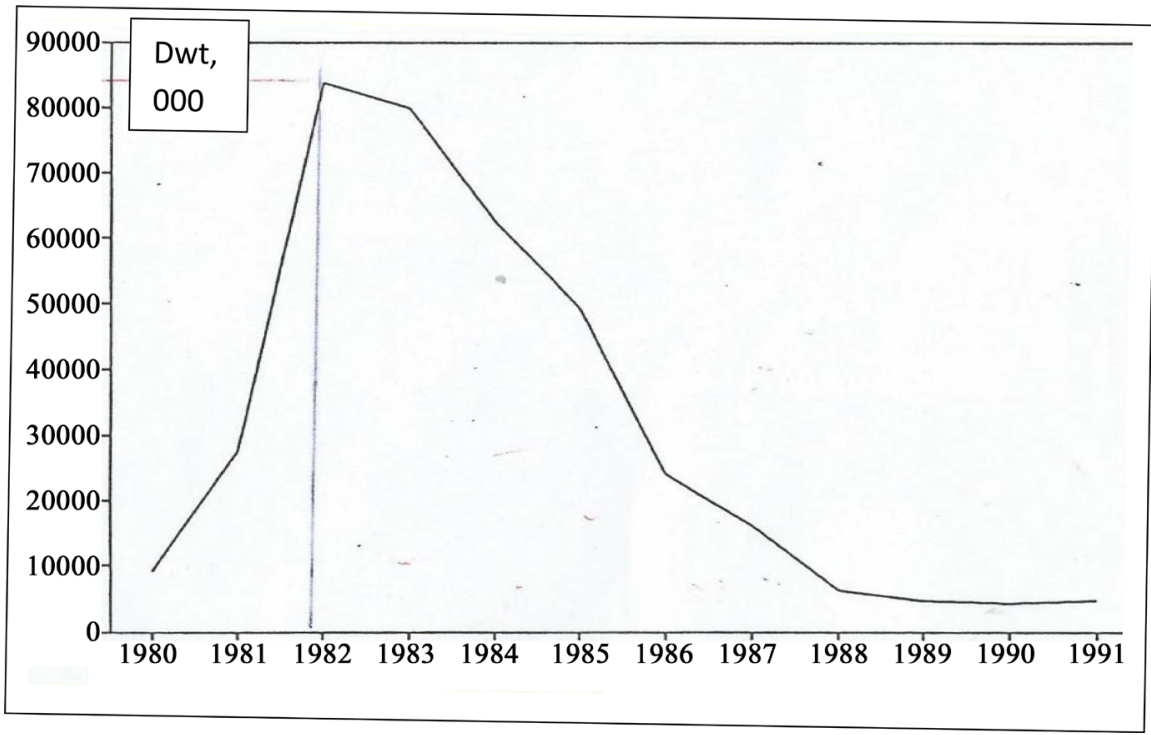

Source: The UK Chamber of Shipping. Modified.

Figure 5. Global trading fleet laid-up, 1980-1991.

Table 1. The years when 8 shipping markets had a low (rock-bottom), 1982-1987.

\begin{tabular}{cccc}
\hline Tramp t-c (index) & Tramp trip charter (index) & Baltic freight (index) & $\begin{array}{c}\text { Grain freight rates, } \\
\text { US-Japan, medium sizes }\end{array}$ \\
\hline Low: July 1982 \& 1986 & Low: July-Aug. 1986 & Low: Aug. 1986 & Low: July 1986; \\
Iron ore from Tub. to Japan & Coal & (1) small clean; (2) medium: (3) large: (4) 250,000 dwt & (1) Gas small; (2) large \\
Low: 1987 & Lows: 1986 and 1987 & (1) low 1985; (2) low 1985; (3) low July/Aug. 1985; (4) & (1) low 1986-June; (2) low \\
& & low July 1985 & 1986-April
\end{tabular}

Source: data from "Fairplay” Info. systems, 1988.

Table 2. The 1985 changes in Greek-owned fleet.

\begin{tabular}{|c|c|c|c|c|}
\hline Additions, numbers & Type & GRT; \%, average size & Less number, reason, GRT, average & Remarks \\
\hline 34 ships & New buildings & $\begin{array}{c}781,354\left(^{*}\right) ; 11 \% \\
22,981 \text { av. }\end{array}$ & 276 ships sold; $4,570,000$; average 16,558 & $\begin{array}{c}\left.{ }^{*}\right) \text { Economies of scale in } \\
\text { new buildings }\end{array}$ \\
\hline 254 ships & $2^{\text {nd }}$ hand & $\begin{array}{c}6,500,000 ; \\
89 \% 25,590 \text { av. }\left(^{* *}\right)\end{array}$ & 286 ships scrapped; $6,100,000 ; 21,329$ av. & $\begin{array}{c}(* *) \text { Economies of scale in } \\
\text { used ships }\end{array}$ \\
\hline Total 288 ships added & & $7.3 m G R T$ & 562 ships removed; $10.7 m$ mRT & $\begin{array}{c}\text { Result: } 3.4 \mathrm{~m} \text { GRT less } \mathrm{x} \\
1.8^{15}=6.1 \mathrm{~m} \text { dwt less }\end{array}$ \\
\hline
\end{tabular}

Source: Data from "Naftica Chronica” journal, yearly editions, 1985.

Clever shipping companies, owning both tankers and dry cargoes, had to read the signs of the days, we reckon, and be prepared for their dry cargo department towards which crisis was coming a year or 18 months later. The world fleet owned about $245 \mathrm{~m}$ dwt of tankers in 1988, and about $60 \mathrm{~m}$ dry cargo plus about $190 \mathrm{~m}$ bulkers, excluding combination carriers (a total of $495 \mathrm{~m} \mathrm{dwt}$ ). Thus, the global shipping companies as a total followed the balance principle among sec-

${ }^{15}$ To transform GRT into DWT we used the equality 1 GRT $=1.8 \mathrm{dwt}$ valid for 1988 data (March). 
tors, but in 1985 this proved to be disastrous, as both sectors hit -one after the other.

Table 2 summarizes the changes in 1985-a crisis year occurred to the Greek-owned fleet.

As shown, 276 ships sold and 286 scrapped in one year $(=562)$ by Greek shipowners, but these ships were smaller than the 254 ones bought (economies of scale). The total fleet, however, did not grow this time as it finally lost $\sim 6 \mathrm{~m} \mathrm{dwt}$. Greek shipowners-as optimistic personalities-from the $2^{\text {nd }}$ half of 1982 to the $1^{\text {st }}$ half of 1983 -ordered 153 ships of $\sim 7 \mathrm{~m} \mathrm{dwt}$ and bought $4-52^{\text {nd }}$ hand ships per week, having a fleet of $47 \mathrm{~m}$ GRT ( $85 \mathrm{~m} \mathrm{dwt}$ ) or 12.5\% of world fleet! Flagging-out noted in 1982-3, intense for the first time, as well about $15 \mathrm{~m}$ dwt high was in lay-up in 1983 (Jan.) (or 764 ships) (Goulielmos, 1998, 2000).

\section{Part II: The Legal Framework Prepared to Repatriate Greek-Owned Foreign Shipping Companies to Greece, 1953-1994}

The above is a topic rarely investigated. Its coin has two sides (Graph 2).

\subsection{History}

The number of shipping offices established by Greeks (Harlaftis, 1996: pp. 270-271) in 1914, were 256 worldwide, and mainly in London, New York and Piraeus. These companies increased, between 1958 and 1990, 3 times, from 352 to 1057. By 1975 , Piraeus obtained ${ }^{16}$ the lion's share with $76 \%$. Surely, it is not only the number of shipping companies that matters, but also their fleet (consolidation).

\subsection{State's Privileges Granted to Foreign Shipping Companies}

The Greek state prepared, in 1953, a legal framework to repatriate about 300 Greek shipping companies, established abroad, to Greece. This was the $1^{\text {st }}$ and most clever attempt with law 2687 (Goulielmos, 2018). In 1968, the Greek dictators also decided to offer certain privileges ${ }^{17}$ to shipping companies so that to

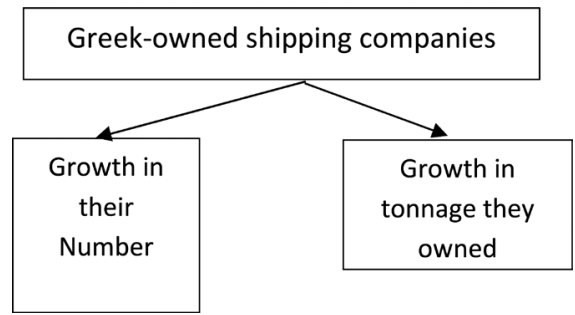

Source: author.

Graph 2. Greek-owned shipping companies.

\footnotetext{
${ }^{16}$ Harlaftis (1996). The return of Greek-owned shipping companies from NY and London to Piraeus coincided with the return of the country to parliamentary democracy in 1974. The return of Greek-owned ships to Greek flag coincided with year 1957 and 1980-1981.

${ }^{17} \mathrm{Re}$-located from Middle East to Greece, in 1967, due to the crisis there. Already given to commercial/industrial foreign companies in 1967 (law 87). This triggered a series of subsequent laws to amend the previous ones.
} 
repatriate them to Greece (law 378/1968 ${ }^{18}$ ). Finally, law 27/1975 (article 25) ruled out that, "the tax-allowances ${ }^{19}$ granted before were aimed at incomes obtained by managing/operating ships, only, if these ships were ocean-going". Article 25 amended further by law 814/1978 (art. 28). Finally, another law (2234/1994) expanded ${ }^{20}$ article 28 of law 814/1978.

As a result of the above, Greeks (Shipping Ministry) started to register-down the number of foreign shipping companies acting in the State, controlled by Greeks (by majority), which transferred their domicile from abroad to Greece, under the special legislation ${ }^{21}$ (Figure 6) and they had to import a certain amount of $\$$ into the country.

Moreover, the Greek state focused its interest on the amount of foreign exchange imported ${ }^{22}$ by the attracted companies-separated in administration cost and in the remaining one-and the personnel employed (local-foreign). In 1992 Greece joined the EU monetary system, and thus the $\$ / €$ parity mattered ${ }^{23}$ thereafter. The number ${ }^{24}$ of shipping companies and the amount of $\$$ imported

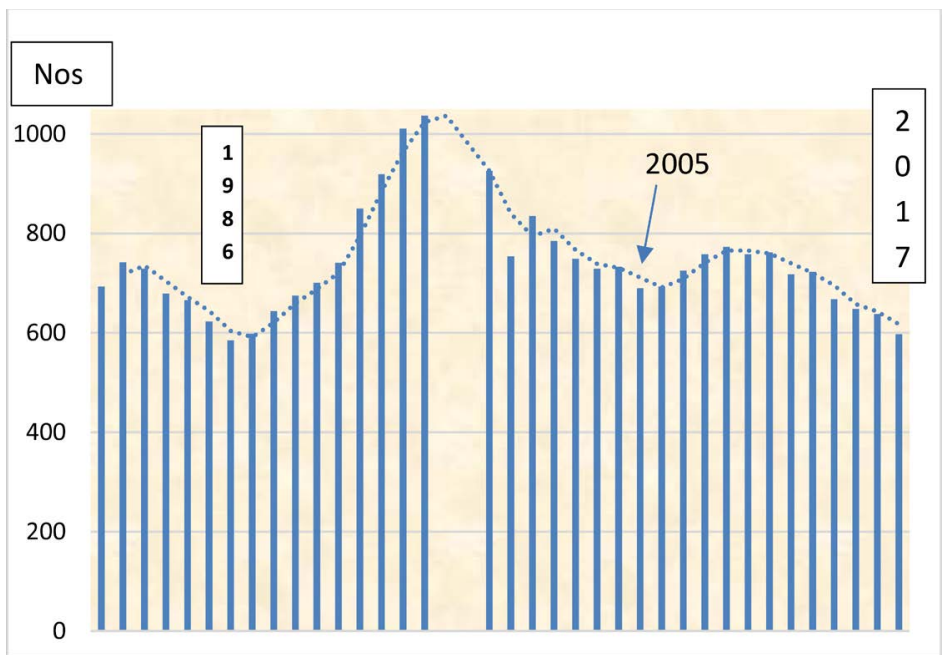

Source: Data from Greek Ministry of Merchant Marine; Athens Center of Planning \& Economic Research, 1988-1992 plan, 1990; PETROFIN Research, 1998-2017.

Figure 6. The number of Greek-owned Marine companies, 1980-2017, repatriated to Greece.

\footnotetext{
${ }^{18}$ The privileges extended to Greek shipping companies already in Greece on the principle of "fair treatment".

${ }^{19}$ The taxation on ships provided between 1989 and 1993 \$ 73m. As declared by the 1974 Prime Minister of Greece "the tax collection from ships was not the objective of his Government".

${ }^{20}$ So that in "shipping" companies to be included and the "companies" managing "tugs/rescue ships" under foreign flags. Including also laws: 1892/1990; 959/1979 legislating the "Special Shipping Company"; 2859/2000.

${ }^{21}$ Laws: 89/1967, 378/1968, 27/1975, 814/1978 and 2234/1994.

${ }^{22}$ The foreign exchange was important for Greeks having a trade deficit all along since the modern Greek state established (in 1830).

${ }^{23} \mathrm{Crew}$ wages for Greeks, since a long time, were paid in English pounds instead in drachmas given frequent devaluations of national currency, especially in 1980-1990.

${ }^{24}$ Worth noting is that $1 / 3$ of the number of companies presented above do not deal with ship management per se (based on 1992 data). So, 572 were exclusive shipping companies managing 2,961 ships (5 ships on average).
} 
were affected by the 1981-1987 depression (Goulielmos, 1997). Between 1982 and 1987, the shipping companies imported $\$ 4.53 \mathrm{~b}$, while between 1988 and 1993 this was $\$ 6.2$ b.

The number of "marine" companies, during 1981-1987 depression, reduced. They fell from 742 to 598 between 1981 and 1987. So, during the depression, 144 marine companies became rather bankrupt. For this we used the indirect criterion that these 144 marine companies were unable to import into Greece the minimum required by the law amount of $\$ 50,000$ per annum (originally $\$ 30,000)$ ! From this we concluded that about 100 (70\%) shipping companies became bankrupt...

\section{Part III: The Creation of the 22 Leading Greek-Owned Shipping Companies, 1970-1985}

The 1970s was a period of a fair orderbook of ships, and the tanker rates were heading to an all-times high. The larger crude carriers, for a period of over 10 years, enjoyed a high ("Worldscale") freight rate index (420 units; $1970=100$ ), till October 1973, when the Arab oil sock suddenly occurred.

Greeks, without knowing when their destiny was going to surprise them, invested heavily, by 1976, in 54 VLCCs (= 11 m dwt; $40 \%$ of their fleet)! This was a grant effort to pursue economies of scale. The implementation of shipping economies of scale initiated by "Onassis" in 1938, and in 1953, who in 1976 owned 18 VLCCs, and the 5 sons of Petros Goulandris, owned 12! Twenty-seven VLCCs were laid-up, however, by 1985 for about 3 or 4 years ${ }^{25}$ already... (Figure 7)!

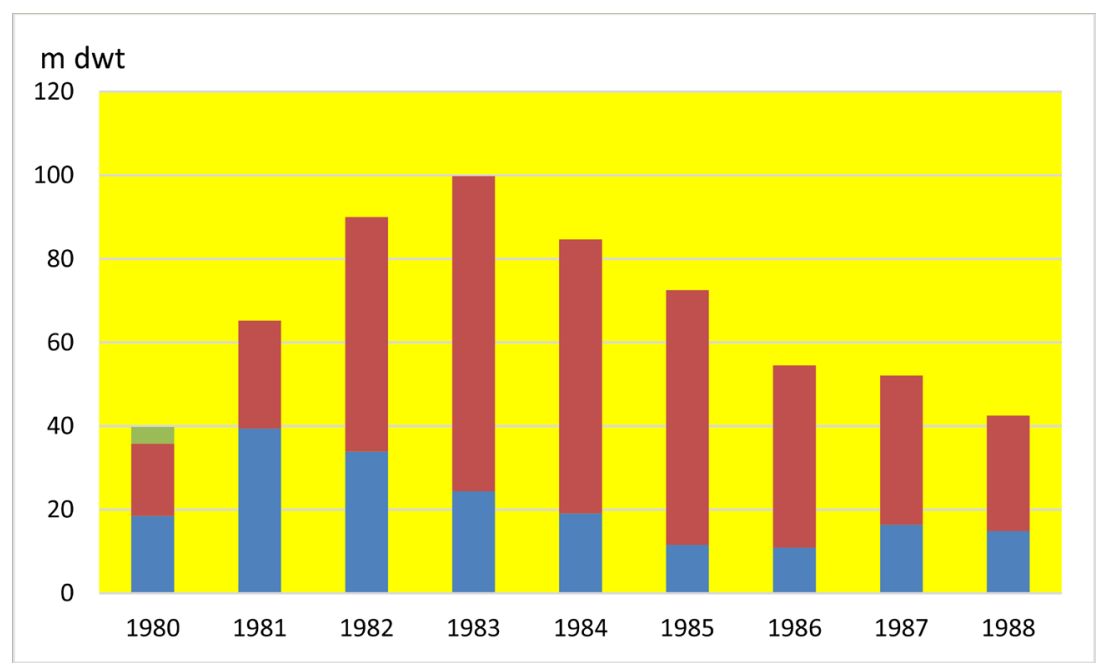

Source: Data from LSE supply \& demand data, 1989.

Figure 7. Tanker tonnage in lay-up and in slow steaming, 1980-1988, for sizes of 150,000 dwt \& over.

\footnotetext{
${ }^{25}$ Greeks used to have ships in lay-up for 3 years before considering scrapping them! Ships with heavy needs of repairs and maintenance, so that to retain their class, being also of certain advanced age, and of a smaller size, they are scrapped by Greeks. Depending on the liquidity problems that a shipping company may have, scrapping — given modern large sizes of ships-may provide a serious amount of dollars given also the price of scrap iron ( $\$ 126-\$ 138$ in this period per ton of steel).
} 
As shown, the larger tankers used to rest in lay-up (75\% in 1983; red columns) and in slow-steaming (blue columns), ranging from $40 \mathrm{~m}$ in March 1980 to $100 \mathrm{~m}$ in $1983^{26}$ and $42.5 \mathrm{~m}$ in 1988 . This was the revenge of the Super tankers... Goliath was beaten... by David once more.

Colocotronis ${ }^{27} \mathrm{M}$, who invested in 2 VLCCs in end 1972, learned a bitter lesson. His case was one of bad timing of economies of scale... He built 400,000 dwt (or 14\% of his fleet), but market fell down between order and delivery, in 1976 (May)...This is why we stressed elsewhere that economies of scale is a good thing, but it depends on the fact that demand for goliath ships has been secured... He used to buy cheap ships and to charter them in period. Finance was obtained on ships' mortgages plus the assignment of earnings. This was, and perhaps still is, the financing practice in Greek shipping. He was accused for a not careful manner of maintaining his fleet (Stokes, 1997: pp. 43-44). The lending banks (Deutsche; Grindlays and European-American syndicate) finally arrested his vessels...

The $19(8+11)$ Greek-owned leading shipping companies, of this period, will be classified in 2 main classes (Graph 3): existing (1970) and newcomers (1985).

The 8-leading shipping companies were: Onassis; Goulandris P \& Sons ("Orion"; "Capeside"), owning more than $4 \mathrm{~m}$ dwt each; Niarchos: $3.40 \mathrm{~m}$; Lemos C M: 2.40 m; Livanos G S; Goulandris N J (Andriaki); Colocotronis M (an ill-fated rising star) and Carras J M, owning $1 \mathrm{~m} \mathrm{dwt} \mathrm{each} \mathrm{(} \mathrm{18} \mathrm{m}$ dwt total) (Figure 8). We estimated that this covered about $35 \%$ of the Greek-owned fleet (1970).

Between 1970 and 1976, the 7, out of the 8, leading companies owned from $\sim 18 \mathrm{~m}$ dwt to $\sim 28 \mathrm{~m}(\sim 55 \%)$. Carras J M and Colocotronis $\mathrm{M}$ left. Colocotronis sold $2.3 \mathrm{~m}$ dwt out of $3.3 \mathrm{~m}$ (60 vessels), of which also 2 VLCCs. In addition, Niarchos sold: $0.3 \mathrm{~m}$; Lemos C M $2.2 \mathrm{~m}$ (total sales of these 3: $\sim 5.1 \mathrm{~m} \mathrm{dwt}$ or 27\% 1976). The 8 leaders covered the $1 / 3$ of the Greek-owned fleet and 1/2 of tankers. The VLCCs surely helped companies in their past rapid tonnage

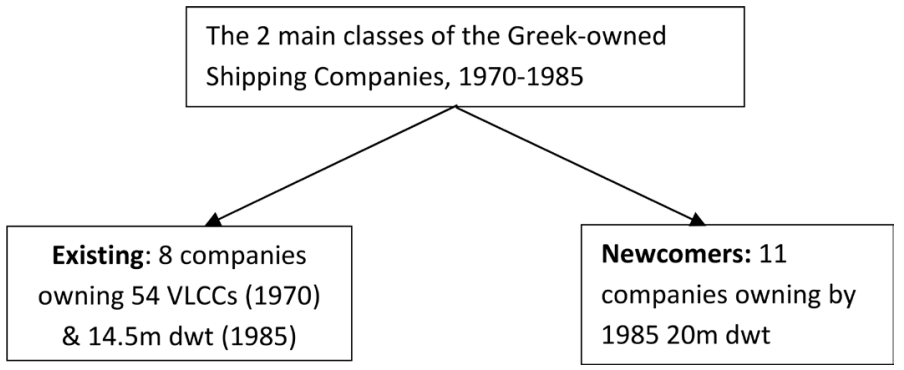

Source: author.

Graph 3. The 2 main classes of the Greek-owned Shipping Companies, 1970-1985.

${ }^{26} \mathrm{It}$ is estimated that in 1983 the world fleet of oil tankers was $263 \mathrm{~m}$ dwt.

${ }^{27}$ In late 1975 "Colocotronis" faced severe liquidity problems and by end 1978 came to an agreement initiated by a consortium led by the "European American Banking Corporation". He is not the only example: "Lemos \& Pateras", \& “Tsavliris" were obliged to reduce their fleets by the banks in 1987, in their endeavors to build ships using a bank loan. The banks got it all wrong to finance shipping companies during a boom (Goulielmos, 2021a)! 


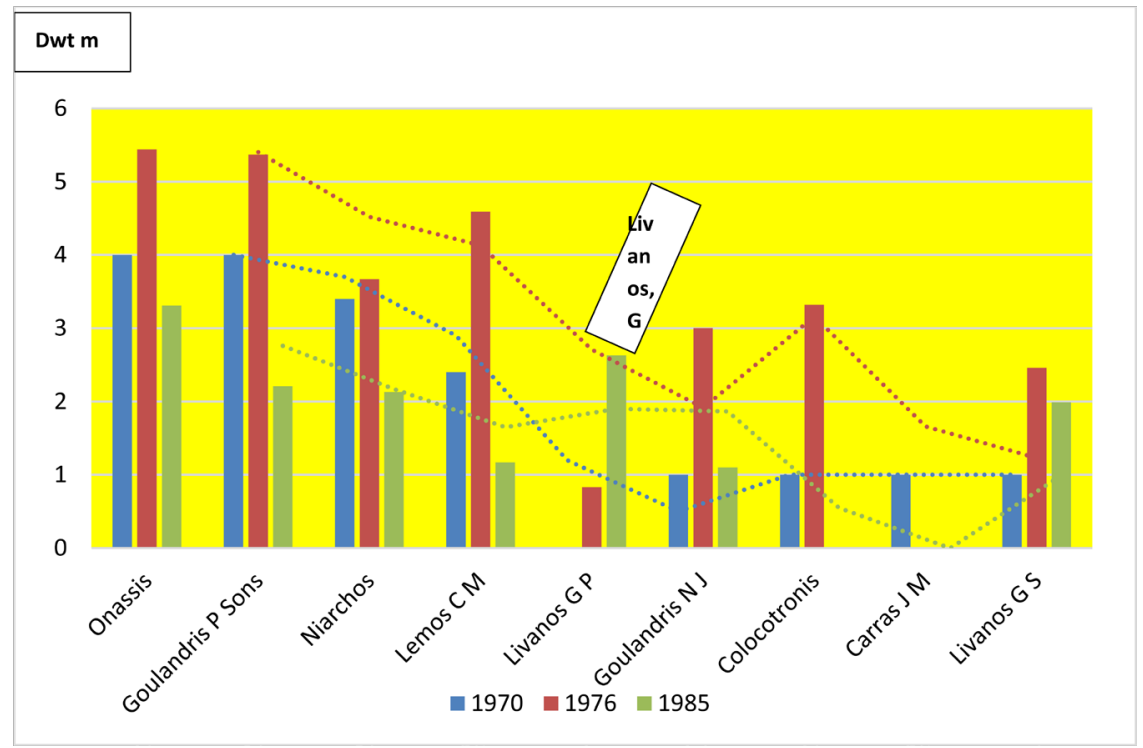

Source: Data from "Naftiliaki” (summer 1985).

Figure 8. The tonnage of the 8 leading shipping companies (plus Livanos G P), 1970-1976-1985.

growth, due to their size of over 200,000 and over each!

A depression is a sad event, no doubt, but while a boom forgives many mistakes, a depression reveals them, and shipowners try hard to survive by policies that they ought to adopt them before! Livanos $\mathrm{G}$ (of Stavros) sold $0.5 \mathrm{~m} \mathrm{dwt}$, since 1976; Onassis $2 \mathrm{~m}$; P Goulandris \& Sons $^{28} 3.2 \mathrm{~m}$; Niarchos $1.54 \mathrm{~m}$ and Goulandris N J $1.9 \mathrm{~m}$ (9.14 m dwt total from these 5). Thus, the leaders, as a result of the depression, sold $1 / 2$ of their fleet. It is true that a crisis puts into a trial capable managers. Moreover, proactive shipowners are something rare.

Interesting is the C. M. Lemos' case because of his drastic downsizing policy:

- He faced the 1981-1987 shipping depression by selling ships heavily, starting in 1983. He sold 44 out of 50 ships (about 90\%) of a total of $3.4 \mathrm{~m}$ dwt out of $4.6 \mathrm{~m}(74 \%)$ ! He believed that shipping depression was going to deepen. From the 44 ships he sold, 16 were scrapped, collecting $\$ 45 \mathrm{~m}$. Moreover, 2 of his vessels (1973-built, 150,000 combis (bulk-oil)), and 3 (mid-1970s-built, VLCCs), were laid-up already for at least 3 years...

- He, and other Greek shipowners, were preoccupied with the question: "How to face a depression"? Some, in late 1970s, reduced shipping exposure, from say $80 \%$ to $25 \%$, by switching ship funds to real estate (popular among Greek shipowners, and Onassis), and buy blue chips, overlooking fleet renewa! Greek shipowners sought to invest in sectors ${ }^{29}$ which were up, when shipping was down -known as "anticycling policy" (Thanopulu, 1996).

${ }^{28}$ By 1993 the 5 sons passed company's shipping management to Petros (of John G) \& Petros (of George G).

${ }^{29}$ This policy found also in the case of "Sanko Shipping Co of Japan", but somehow different. Sanko invested heavily and exclusively in tankers in 1970s, but it derived heavy losses. Then it decided to invest heavily in dry cargo ships in 1980s to counter the previous losses. But timing was wrong (Stopford, 2009: p. 126; Couper et al., 1999). 
The above policy conforms with the popular saying: "do not put all eggs in one basket", especially if this basket gets smaller at times and larger at others... Bacolitsas $^{30}$ argued that "despite the doom and gloom that the shipping market experienced during 2011-13, and especially during 2012, Greek shipowners placed newbuilding orders..." He admitted that there were low prices in various shipyards, close to historical lows, and new designs more efficient in emissions and fuel consumption... Goulielmos (2020b) described the growth policy of Greek shipowners. This implies that opportunities, par excellence, do arise during a depression, but only liquid ${ }^{\beta 1}$ companies grasp them...

A depression (and not capitalism) seems to make rich people richer and poor people poorer, as experience taught us and them. Finally, a shipowner cannot ignore what is "legal obsolescence" as far as $\mathrm{CO}_{2}$ emissions are concerned. Whether a shipowner protects the environment or not, it is the Charterer (customer) who will make him/her to comply with IMO regulations!

- Further, one may downsize one's fleet, say to $10-12$ ships, or to that size where losses are tolerated, retaining the essential expertise and the feel of the market, watching-out there when market is going to improve ${ }^{32} \ldots$

- Downsizing applied frequently in non-shipping companies, especially after end-2008. This is the successor of the "laying-off". Downsizing is the planned elimination ${ }^{33}$ of jobs (Robbins \& Coulter, 2018: p. 466). For this, an economic recession is one cause, the too many employees, and the failure of management, etc., are the 2 others. In shipping, owning no ships, or managing a reduced number of ships, are the main reasons for downsizing (Thenamaris in 1990s).

The eleven "newcomers" (Figure 9) appeared stronger out of the 1981-1985

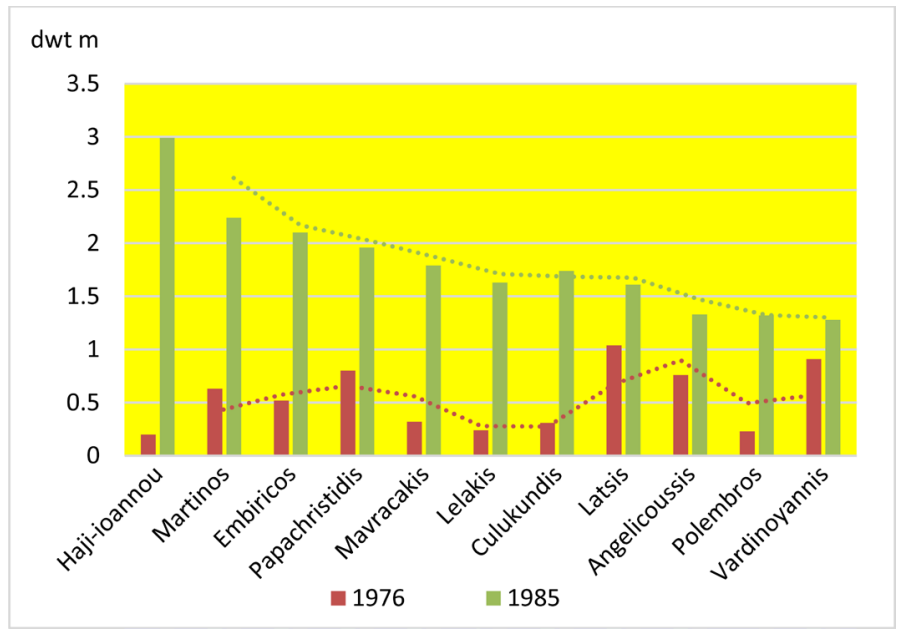

Source: as in Figure 5.

Figure 9. The fleets of the 11 newcomers, 1976-1985.

\footnotetext{
${ }^{30}$ Director of Sea Pioneer Shipping: 278,000 dwt in 2015 ("Naftika Chronica” journal 2013).

${ }^{31}$ There is no stronger proof than this about the real value of liquidity!

${ }^{32} \mathrm{~A}$ case reported when a Greek shipowner retained all his/her staff for 3 years ... owning no ships. Lemos from 50 ships in 1976 retained 6 in 1985 (from $4.6 \mathrm{~m}$ dwt to $1.2 \mathrm{~m}$ ).

${ }^{33} 12$ at least large international companies applied downsizing, including Nokia, Dell, GM, Siemens (since 1981).
} 
depression in 1985! The leading companies increased to 18 from 7, owning 34.5 $\mathrm{m}$ dwt from about $31 \mathrm{~m}$ in 1976, estimated to cover about $38 \%$ of the Greek-owned fleet. Do depressions create growth...? They do. These 11 new leading companies demonstrated that Greek-owned fleet growth does not rest exclusively on traditional shipowners!

Table 3 illustrates closer these 11 newcomers who-among a crisis-joined the leading ones in 1985.

\section{Part IV: How the Greek-Owned Shipping Companies Survived from the 1981-1987 Depression}

Years 1986-1988 brought 12 fundamental changes (!) in the post-depression Greek-owned shipping companies, which are worth noting. This we consider to be a new era for Greek-owned shipping (since end 1987).

- Greeks returned to the Very \& Ultra large tankers (VLCCs \& ULCCs): from 54 in 1976 to 74 in 1988! 13 owners, out of 22, owned VLCCs/ULCCs, while 2 owned also Suezmax (120 - 200,000 dwt each).

- They invested in "combination carriers" (Oil, Ore, Bulk). This was a lesson learned by the 1981-1987 depression: ships ought to be flexible, and able to carry 2 - 3 different cargoes (Stopford, 2009: pp. 601-603).

- They abandoned Greek flag, (flagging-out), massively.

- They played with assets.

Table 3. The main characteristics of the 11 Greek-owned companies owning fleets $\geq 1 \mathrm{~m}$ dwt by 1985 .

\begin{tabular}{|c|c|c|c|}
\hline Company & Characteristics & Company & Characteristics \\
\hline $\begin{array}{l}\text { “Troodos” (1961)- } \\
\text { Hajiioannou L-Greek/Cypriot; } \\
7 \text { ships (1976): 201,461 dwt; }\end{array}$ & 21 tankers, $\sim 3 \mathrm{~m} \mathrm{dwt} \mathrm{(1985)}$ & $\begin{array}{l}\text { Thenamaris (1969-70)-made-up } \\
\text { of } 3 \text { brothers plus their Mother } \\
\text { Athina-38 ships } 634,872 \mathrm{dwt} \text { (in } \\
\text { 1976) }\end{array}$ & $\begin{array}{l}58 \text { ships, } 2.24 \mathrm{~m} \text { (1985); fleet variety: } \\
\text { general cargo-box-heavy } \\
\text { lifters-bulk-bulk/ore-product } \\
\text { carriers-tankers-car carriers }\end{array}$ \\
\hline $\begin{array}{l}\text { “Mayamar”, } \\
\text { Mavracakis J (1968) }\end{array}$ & $\begin{array}{l}\text { Considered a clever trader, buyer \& } \\
\text { seller of tankers, focusing on the } 85 \\
-135,000 \mathrm{dwt} \text { range; } 1.8 \mathrm{~m} \mathrm{dwt}\end{array}$ & Lelakis Antonis (1971) & $\begin{array}{l}44 \text { ships, } 1.63 \mathrm{~m} \mathrm{dwt} \text {; applying timing } \\
\text { to } 2^{\text {nd }} \text { hand market \& good bargains } \\
\text { out of enforced auctions ("E Hsu" } \\
\text { ships \& ships destined to be scrapped) }\end{array}$ \\
\hline $\begin{array}{l}\text { Ceres, Livanos G P }\left(^{*}\right)(1976) \\
\text {-traditional }\end{array}$ & $\begin{array}{l}73 \text { ships, } 2.63 \mathrm{~m} \mathrm{dwt} \text {; } 50 \text { delivered } \\
\text { in } 1969-1972 \text {-mini-bulkers } 3100 \\
\text { dwt (innovator) }\end{array}$ & $\begin{array}{l}\text { Buenamar, Embiricos family, } \\
\text { (mid-1970s) - traditional-from } \\
\text { Andros }\end{array}$ & $\begin{array}{l}28 \text { ships, } 2.10 \mathrm{~m} \text { dwt; managed by } \\
\text { Epaminondas }\end{array}$ \\
\hline $\begin{array}{l}\text { Hellespont, } \\
\text { Papachristidis Fr. (founder); son: } \\
\text { Basil; }\left(^{* *}\right)\end{array}$ & $\begin{array}{l}24 \text { ships, } 1.96 \mathrm{~m} \mathrm{dwt} ; 8 \text { tankers in } \\
85 \text { - } 125,000 \text { range; bareboat } \\
\text { charters of } 3 \text { - } 7 \text { years }\end{array}$ & $\begin{array}{l}\text { Polembros, Polemis Spy. (1976) } \\
\text { —traditional }\left(^{* * *}\right)\end{array}$ & 17 ships, $1.32 \mathrm{~m} \mathrm{dwt}$ \\
\hline $\begin{array}{l}\text { C Ventures } \mathrm{NY}- \\
\text { Culukundis-traditional }\end{array}$ & 12 ships, $1.74 \mathrm{~m} \mathrm{dwt}$ & Bilinder, Latsis $\mathrm{J}\left({ }^{* * *}\right)$ & $\begin{array}{l}24 \text { ships, } 1.61 \mathrm{~m} \mathrm{dwt} \text {; in banking \& } \\
\text { refineries }\end{array}$ \\
\hline $\begin{array}{l}\text { Varnima, Vardinoyannis, with a } \\
\text { Greek-based refinery }(* * * * *)\end{array}$ & 34 ships, $1.28 \mathrm{~m} \mathrm{dwt}$ & Total 11 companies $\rightarrow$ & $20 \mathrm{~m}($ from $6 \mathrm{~m}$ dwt in 1970) \\
\hline
\end{tabular}

${ }^{*}$ ) Traditional (Chios); led by John P. Livanos (Captain)—-merchant \& shipowner (1824); his son George passed away in 1988. The company became stronger during the interwar period due to good freight rates at that time. He stablished a NY office (the "Seres"; 1950). Eventually, George-John's nephew-became manager with 4 liberty ships and 1 steam-tanker newly built (1955). The small bulk carriers destined to serve the lakes (the grain trade in the Great lakes of USA \& Canada). This was an act of "anti-economies of scale"! Another Livanos is George of Stavros (1958). (**) Greek-Canadian. ( $\left.{ }^{* * *}\right)$ Spyros and Adamantios from Andros. $\left(^{* * * *)}\right.$ From Peloponnesus. ${ }^{(* * * *)} 2$ brothers, from Crete. 
- They invested in oil Product carriers, RoRos, and Chemical tankers (for the $1^{\text {st }}$ time).

- They bought cheap ships spending $\$ 1 \mathrm{~b}$.

- They reduced costs

- Their participation in general cargo ships fell.

- They faced finance problems.

- They increased their share in containerships up to 75,000 TEUs (TEU = 20-foot equivalent unit).

- They improved their relations with shipyards.

- Certain owners were in disadvantage as far as the \$ parity with shipbuilding currencies is concerned, especially with Yen.

The comeback of Greek owners to very large tankers, and to Suezmax (1 m barrels), increased the Greek-owned shipping to $85-88 \mathrm{~m} \mathrm{dwt} \mathrm{(March,} \mathrm{1988),} \mathrm{or}$ $14 \%$ of world shipping, reaching Japan and staying ahead of USA (68 m dwt) and Hong Kong (48 m). Graph 4 outlines the 3 major changes.

The 22 leading shipowners presented (Figure 10), covered more than 1/2 of the Greek-owned tonnage (in 1986-1988) and were 6 more than 1986.

The above 22 owned 714 ships (1988); they increased by $4 \mathrm{~m}$ dwt and 4 additional companies (=41.2 m dwt; 685 ships in 1986). Four companies dropped down: Papachristidis, Lelakis, Culukundis, and Lemos C M. Eight companies climbed-up: Tavulareas, Kollakis, Callimanopulos, Tsakos ${ }^{34}$, Pegasus, Hadjipaters, Alafouzos \& Venamis/Gab. ${ }^{35}$ (Table 4). Moreover, Greeks passed the shipping depression by applying all possible methods of reducing their costs. Greeks argued that Greek flag cost them about $\$ 650$ per day. Greeks returned to VLCCs and ULCCs aimed at transporting the Iranian crude oil from the Kharg island (at Hormuz narrow pass) to Arabian Gulf.

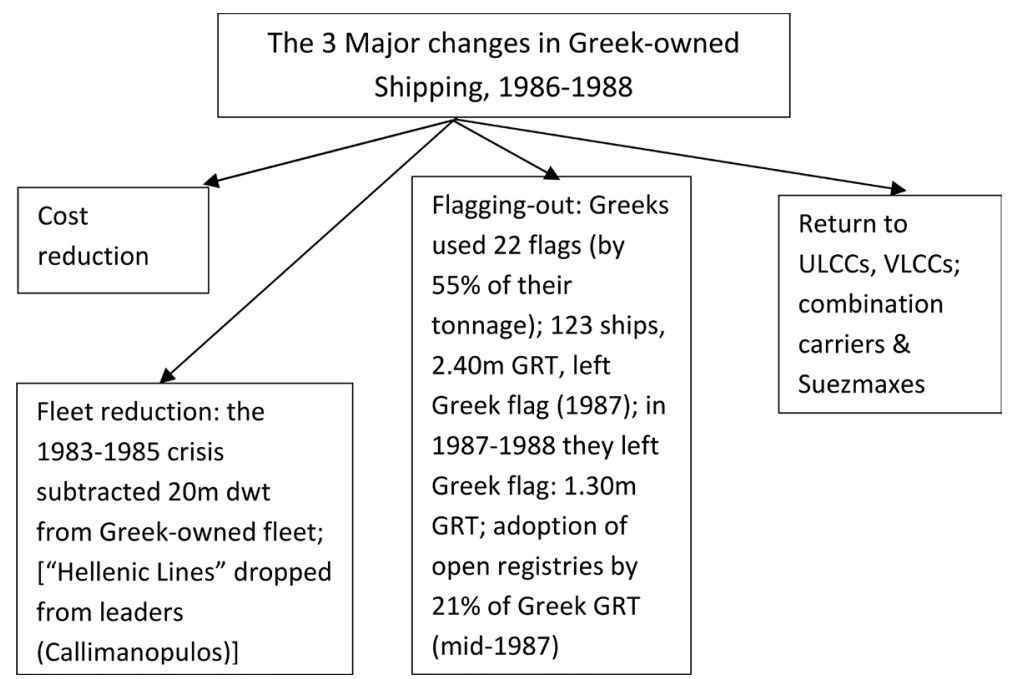

Source: author.

Graph 4. The 3 major changes in Greek-owned shipping, 1986-1988.

\footnotetext{
${ }^{34}$ From Chios; having 2 companies listed in London SE.

${ }^{35}$ From Cephalonia.
} 


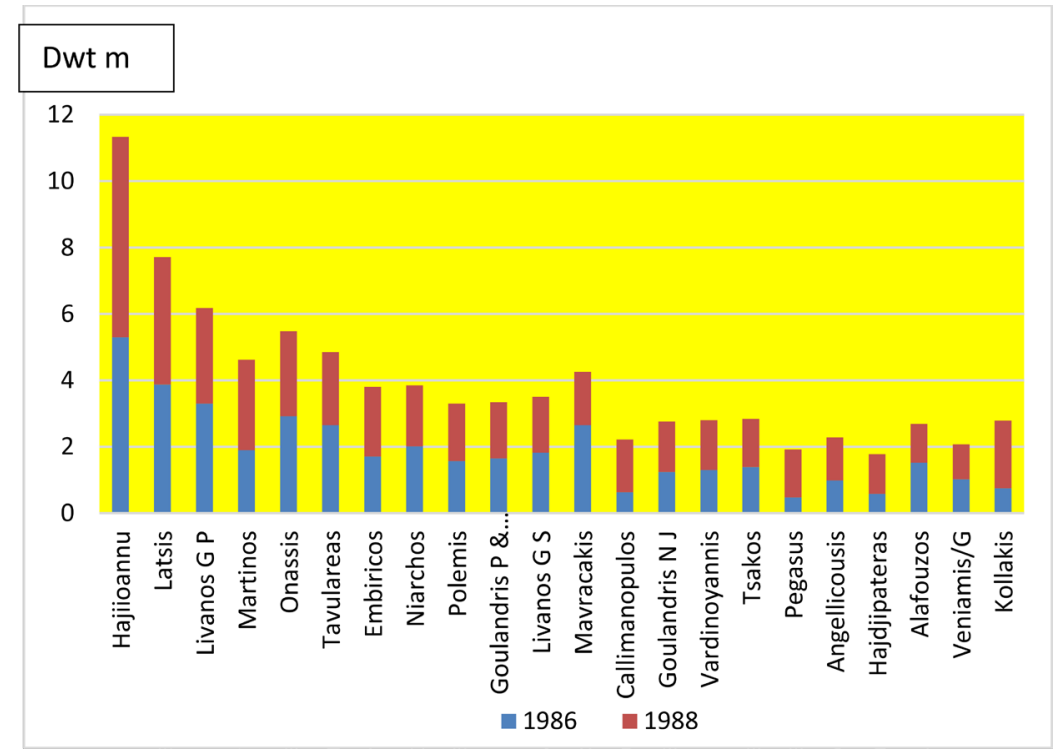

Source: Data from "Naftiliaki” Journal, 1988 Summer.

Figure 10. The 22 leading Greek-owned shipping companies, 1986-1988.

Table 4. The 1986-1988 developments in 22 leading Greek-owned companies.

\begin{tabular}{|c|c|c|c|c|c|}
\hline Company & $\begin{array}{l}\text { Changes, 1986-1988, } \\
\text { dwt m, ship no. }\end{array}$ & Remarks & Company & $\begin{array}{l}\text { Changes, 1986-1988 } \\
\text { dwt m, ship no. }\end{array}$ & Remarks \\
\hline $\begin{array}{l}\text { Haji-Ioannou } \\
\text { (tankers) }\end{array}$ & $\begin{array}{l}5.3-6.03=\text { plus } 734,000 \\
42-45=\text { plus } 3 \text { ships }\end{array}$ & $\begin{array}{l}\text { Specialized in medium age } \\
\text { tankers serving Iranian Sea; } \\
\text { since } 1985 \text { he bought } 3 \mathrm{~m} \mathrm{dwt} \mathrm{of} \\
\text { an increasing size }(>170,000 \mathrm{dwt} \\
\text { each) }\end{array}$ & $\begin{array}{l}\text { Latsis } \\
\text { J-“Bilinder" }\end{array}$ & $\begin{array}{l}3.87-3.84=\text { less } \\
28,351 ; \\
77-87=\text { plus } 10\end{array}$ & $\begin{array}{l}\text { Preference to Greek flag; } \\
\text { variety in ships: general } \\
\text { cargo, RoRo, gas, } \\
\text { pontoons, passenger \& } \\
36 \text { tugs; he bought } 5 \\
\text { ULCCs (1985-6) }\end{array}$ \\
\hline $\begin{array}{l}\text { Livanos, G P; } \\
\text { "Ceres" }\end{array}$ & $\begin{array}{l}3.30-2.88=\text { less } 419,943 \\
96-87=\text { less } 9\end{array}$ & $\begin{array}{l}\text { Delivery of } 7 \text { newly-built tankers } \\
+1 \text { Probo; sold the old, } \\
\text { well-maintained, mini bulkers; } \\
\text { sold also super tankers; \& } 7 \\
\text { product carriers of advanced } \\
\text { technology; he spent } \$ 45 \mathrm{~m} \text { for } 2 \\
\text { OBO of low age }\end{array}$ & Thenamaris & $\begin{array}{l}1.9-2.72=\text { plus } \\
815,218 ; 43-63=\text { plus } \\
20\end{array}$ & $\begin{array}{l}\text { The Malta flag gained } 47 \\
\text { bulks from Cypriot flag } \\
\text { due to Turkish embargo; } \\
\text { Dry bulks; } 12 \text { bought in } \\
1987\end{array}$ \\
\hline Onassis & $\begin{array}{l}2.92 \mathrm{~m}-2.56=\text { less } \\
362,957 ; 29-25=\text { less } 4\end{array}$ & $\begin{array}{l}\text { Modern bulk; reduction in } \\
\text { tonnage }\end{array}$ & Niarchos & $\begin{array}{l}2.01 \mathrm{~m}-1.84=\text { less } \\
178,474 ; \\
29-26=\text { less } 3\end{array}$ & Like Onassis \\
\hline $\begin{array}{l}\text { Empiricos } \\
\text { (Buenamar) }\end{array}$ & $\begin{array}{l}1.71-2.1=\text { plus } 395,782 \\
26-23=\text { less } 3\end{array}$ & $\begin{array}{l}3 \text { large Combined carriers/ } \\
\text { Suezmax } \\
\text { (1987) arriving at } 9 \text { (most } \\
\text { Suezmax) }\end{array}$ & Vardinoyiannis & $\begin{array}{l}1.3-1.5=\text { plus } \\
199,839 ; 40-58=\text { plus } \\
18\end{array}$ & $\begin{array}{l}\text { He obtained newly built } \\
\text { general cargo ships } \\
\text { valued } \$ 230 \mathrm{~m}(1988) \\
\text { plus product tankers }\end{array}$ \\
\hline $\begin{array}{l}\text { Tavulareas/ } \\
\text { Atlas }\end{array}$ & $\begin{array}{l}2.65-2.20=\text { less } 447,691 \\
14-12=\text { less } 2\end{array}$ & & $\begin{array}{l}\text { Callimanopulos } \\
\text { (Trade \& } \\
\text { Transport) }\end{array}$ & $\begin{array}{l}0.63-1.59=\text { plus } \\
962,365 ; 10-16=\text { plus } \\
6\end{array}$ & $\begin{array}{l}\text { Serving Persian Gulf; } \\
\text { bought } 6 \text { large tankers \& } \\
\text { combis, 1986-88; plus } 2 \\
\text { large oil/ore carriers }\end{array}$ \\
\hline $\begin{array}{l}\text { Kollakis-(Kap } \\
\text { pa Mar.) }\end{array}$ & $\begin{array}{l}0.75-2.035=\text { plus } \\
1,280,176 ; 16-37=\text { plus } \\
21\end{array}$ & $\begin{array}{l}\text { Attracted by good freight rates } \\
\text { for large (VLCCs) tankers for P. } \\
\text { Gulf; reefers \& bulkers }\end{array}$ & $\begin{array}{l}\text { Polemis S. (L \& } \\
\text { W) }\end{array}$ & $\begin{array}{l}1.57-1.73=\text { plus } \\
164,016 ; 20-23=\text { plus } \\
3\end{array}$ & $\begin{array}{l}\text { "ProBulk" in } 1987 ; 4 \\
\text { new-buildings; carrying } 4 \\
\text { m tons in } 1 \text { year }\left(^{*}\right) \text { plus } \\
4 \text { chartered-in }\end{array}$ \\
\hline
\end{tabular}




\section{Continued}

\begin{tabular}{|c|c|c|c|c|c|}
\hline $\begin{array}{l}\text { Goulandris P \& } \\
\text { sons }\end{array}$ & $\begin{array}{l}1.65-1.69=\text { plus } 36,502 \\
15-14=\text { less } 1\end{array}$ & & Livanos G S & $\begin{array}{l}1.82-1.68=\text { less } \\
139,765 ; 18-12=\text { less } \\
6\end{array}$ & \\
\hline Mavracakis & $\begin{array}{l}2.65-1.61=\text { less } \\
1,047,285 ; 21-15=\text { less } 6\end{array}$ & Sold ships due to higher prices & $\begin{array}{l}\text { Veniamis/ } \\
\text { Gabriel }\end{array}$ & $\begin{array}{l}1.02-1.06=\text { plus } \\
37,742 ; 35-35\end{array}$ & Renewal program \\
\hline $\begin{array}{l}\text { Alafouzos Arist. } \\
\text { (Glafki) }\end{array}$ & $\begin{array}{l}1.52-1.17=\text { less } 342,912 ; \\
28-20=\text { less } 8\end{array}$ & $\begin{array}{l}\text { Delivered ordered bulkers after } \\
\text { sold to Chinese! }\end{array}$ & $\begin{array}{l}\text { Hadjipateras } \\
\text { (Peninsular } \\
\text { Mar.) }\end{array}$ & $\begin{array}{l}0.58-1.20=\text { plus } \\
622,002 ; 3-5=\text { plus } 2\end{array}$ & He bought large tankers \\
\hline Tsakos & $\begin{array}{l}1.39-1.45=\text { plus } 62,044 \\
30-26=\text { less } 4\end{array}$ & & $\begin{array}{l}\text { Goulandris N J } \\
\text { (Andriaki) }\end{array}$ & $\begin{array}{l}1.24-1.52=\text { plus } \\
278,347 ; 25-22=\text { less } \\
3\end{array}$ & \\
\hline $\begin{array}{l}\text { Pegasus (in a } \\
\text { shipowners' } \\
\text { pool) }\end{array}$ & $\begin{array}{l}0.48-1.44=\text { plus } 965,351 ; \\
25-16=\text { less } 9\end{array}$ & $\begin{array}{l}\text { Sale of } 3 \text { bulkers getting } \$ 35 \mathrm{~m} \& \\
\text { buying } 2 \text { VLCCs \& } 1 \text { tanker } \\
118,000 \text { tons; } 2 \text { VLCCs bought } \\
\text { in } 1987 \text {; cancelled orders in } \\
\text { Japan for general cargoes }\end{array}$ & Angelicoussis A & $\begin{array}{l}0.98-1.3=\text { plus } 0.32 \\
43-47=\text { plus } 4\end{array}$ & \\
\hline Total 22 & $41 \mathrm{~m}$; 685 ships & $<--1986$ & $1988 \rightarrow$ & $45 \mathrm{~m} ; 714$ ships & Economies of scale \\
\hline
\end{tabular}

$\left.{ }^{*}\right)$ A pool consisting of Polemis and Papachristidis, providing management services to other shipowners like Thenamaris.

Two companies ("Pegasus" and "Callimanopulos 36 "/"Trade \& Transport"), showed a preference towards super tankers/Combis (a paradigm shift). Greeks reduced also their "general cargoes ships" by $41 \%$ since 1981 (owning $8 \mathrm{~m} \mathrm{dwt} \mathrm{in}$ 1988 against 13.5 in Greek flag) to derive funds to buy bulkers.

Moreover, the crisis deteriorated the relations between shipowners and shipyards, because shipowners tried to: postpone ships' delivery; cancel it; refuse... to pay; ask for a reduced price and... abandoning ships to shipyards... The self-interest has prevailed. A bad parity between $\$$ and Japanese Yen wounded certain Greek shipowners ignoring to buy Yens forward.

Greek shipowners are always ready... to help either shipyards, or banks, to get rid of ships abandoned by their original owners (e.g., as happened in Korean \& Brazilian yards). Greeks emerged as a... "Salvation Army" for the Shipyards, and banks, including bankrupt shipping companies. Greeks always sought-after opportunities worldwide.

An asset play played in mid-1985-autumn-1987 by Greek shipowners. They paid $\$ 29.5 \mathrm{~m}$ in $1985-1987$ to buy 7 ships and sold them against $\$ 72.2 \mathrm{~m}$ deriving almost $\$ 43 \mathrm{~m}$ profit (ships from $4-17$ years of age and from $32,680 \mathrm{dwt}$ to 123,247 dwt each, to Chinese and Norwegians). In a depression finance becomes rare, but Greeks continued to have the support of the banks.

It is remarkable, and we have to underline this here, that almost 12 beneficial" effects within only 3 -years provided by the depression. The depression created or restored 22 Greek-owned shipping companies by owning $45 \mathrm{~m}$ dwt (plus $4 \mathrm{~m}$ dwt in 3 years).

\footnotetext{
${ }^{36}$ Son of Pericles; P known to specialize in liners (cargo) hit bad in 1980s crisis. Gregory, his son, specialized in tramps.
} 


\section{Part V: The 1993-1995 Period}

In 1993, 27 leading ${ }^{37}$ owners existed, 5 more than in 1988, with $\sim 55 \mathrm{~m} \mathrm{dwt}$ (895 ships), $60 \mathrm{~m}$ in 1994 (915 ships) and $70 \mathrm{~m}$ in 1995 (Table 5); 4 companies advanced-up and 1 dropped-down.

Table 5. The 31 leading owners, 1993-1995.

\begin{tabular}{|c|c|c|c|c|}
\hline Companies & $\begin{array}{l}1993 \text { dwt } \\
\text { m-ships }\end{array}$ & $\begin{array}{l}1994 \text { dwt } \\
\text { m-ships }\end{array}$ & $1995 \mathrm{dwt} \mathrm{m}\left(^{*}\right)$ & Remarks (1994) \\
\hline \multirow{2}{*}{ Livanos G P (1) } & 6.39 & 6.94 & 5.35 & \multirow{2}{*}{22 G C; 23 passenger.; $22 \mathrm{t}$} \\
\hline & 106 & 101 & - & \\
\hline \multirow{2}{*}{ Latsis John (2) } & 3.63 & 4.10 & 4.10 & \multirow{2}{*}{$23 \mathrm{t} ; 38$ tugs } \\
\hline & 85 & 88 & - & \\
\hline \multirow{2}{*}{ Haji-Ioannou (3) } & 3.12 & 3.74 & 3.74 & \multirow{2}{*}{ Scrapping program; selling policy for 5 years } \\
\hline & 23 & $28 \mathrm{t}$ & - & \\
\hline \multirow{2}{*}{ Thenamaris $\left(^{* *}\right)(4)$} & 1.87 & 3.36 & 3.36 & \multirow{2}{*}{$\begin{array}{l}\text { One of the } 3 \text { brothers. Ath. established his own } \\
\text { company("Eastern"); } 25 \text { t; } 3 \text { VLCCs }\end{array}$} \\
\hline & 49 & $\begin{array}{c}49 \\
\text { strong growth }\end{array}$ & - & \\
\hline \multirow{2}{*}{ Embiricos (5) } & 3.47 & 3.54 & 3.65 & \multirow{2}{*}{$13 \mathrm{t}$} \\
\hline & 25 & 26 & - & \\
\hline \multirow[t]{2}{*}{ Angelicoussis (6) } & 2.65 & 3.24 & 3.13 & \multirow{2}{*}{$33 \mathrm{~b} \mathrm{c} ; 4$ from auction; 1 VLCC } \\
\hline & 48 & 49 & - & \\
\hline \multirow{2}{*}{ Papachristidis (7) } & 3.10 & 2.87 & 3.40 & \\
\hline & 15 & $13 \mathrm{t}$ & - & \\
\hline \multirow{2}{*}{ Polemis A \& S (8) } & 2.55 & 2.63 & 3.20 & \multirow{2}{*}{ Partners will, most probably, split-off; $16 \mathrm{t}$} \\
\hline & 25 & 26 & - & \\
\hline \multirow{2}{*}{ Tsakos (9) } & 2.12 & 2.61 & 2.66 & \multirow{2}{*}{$\begin{array}{l}\text { Global Ocean Carriers; MIF raised end-1993\$34 m } \\
\text { from OSLO SE; } 21 \mathrm{t}\end{array}$} \\
\hline & 34 & 46 & - & \\
\hline \multirow{2}{*}{ Livanos G S (10) } & 2.55 & 2.44 & 2.00 & \multirow{2}{*}{ Fleet renewal program; $8 \mathrm{~b} \mathrm{c}$} \\
\hline & 18 & 16 & - & \\
\hline \multirow{2}{*}{ Alafuzos-non-traditional (11) } & 1.63 & 2.17 & 2.40 & \multirow{2}{*}{$21 \mathrm{t}$} \\
\hline & 25 & 35 & - & \\
\hline \multirow{2}{*}{ Onassis (12)—non traditional } & 2.16 & 1.99 & 2.00 & \multirow{2}{*}{ Fleet renewal since $1991 ; 10 \mathrm{t}$} \\
\hline & 20 & 18 & - & \\
\hline \multirow{2}{*}{$\begin{array}{l}\text { Zissimatos Panagis (NB) (13)- } \\
\quad \text { traditional (Cephalonia) }\end{array}$} & 2.19 & 1.84 & 2.60 & \multirow{2}{*}{$40 \mathrm{t}$} \\
\hline & 87 & 64 & - & \\
\hline \multirow{2}{*}{$\begin{array}{c}\text { Procopiou (14) } \\
\text { Bros (Dimitris \& G.) (new) }\end{array}$} & 0.67 & 1.78 & 2.80 & \multirow{2}{*}{$\begin{array}{c}4 \text { companies: Dynacom-Centrofin (\#)-Agency } \\
\text { Trust-Sea traders; } 13 \mathrm{~b} \mathrm{c}\end{array}$} \\
\hline & 20 & $\begin{array}{l}29 \\
\text { up }\end{array}$ & - & \\
\hline \multirow{2}{*}{ Goulandris P Sons (15) } & 1.97 & 1.67 & 1.60 & \multirow{2}{*}{$7 \mathrm{t} ; 7 \mathrm{~b} \mathrm{c}$} \\
\hline & 16 & 15 & - & \\
\hline Veniamis/Gabriel (16) & 1.20 & 1.51 & 2.00 & $24 \mathrm{bc}$ \\
\hline & 25 & 28 & - & $24 \mathrm{DC}$ \\
\hline Vardinoviannis (17) & 1.39 & 1.45 & 1.46 & $32 t$ \\
\hline 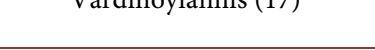 & 49 & 42 & - & $22 \mathrm{l}$ \\
\hline & $\begin{array}{l}{ }^{37} \text { Onassi } \\
\text { Gouland } \\
\text { tankers. }\end{array}$ & $\begin{array}{l}\text { sted in a } 303,0 \\
J \text { ( } \$ 65 \mathrm{~m}) \text {, "L } \\
\text { ngel" in a bulk }\end{array}$ & $\begin{array}{l}00 \text {-dwt tanker }(\$ 1 \\
\text { OFS" }(2 ; \$ 124 \mathrm{~m}) \text {, } \\
\text { ar of } 162,000 \mathrm{dwt}(\end{array}$ & $\begin{array}{l}5 \mathrm{~m}) \text {; “Thenamaris" ( } \$ 168 \mathrm{~m}) \text {, Lemos C M ( } \$ 65 \mathrm{~m}) \text {, } \\
\text { Ath. Martinos ( } \$ 64 \mathrm{~m}) \text { in } 6 \times 148,500-150,000 \mathrm{dwt} \\
53 \mathrm{~m}) \text {. }\end{array}$ \\
\hline
\end{tabular}




\section{Continued}

\begin{tabular}{|c|c|c|c|c|}
\hline $\begin{array}{l}\left.\text { Manios Dim. }{ }^{* * *}\right)(18) \\
\text { Transman-Transoil (new) }\end{array}$ & $\begin{array}{c}0.33 \\
11\end{array}$ & $\begin{array}{c}1.43 \\
18 \\
\text { up }\end{array}$ & $\begin{array}{c}1.80 \\
-\end{array}$ & 7 t; 1 ULCC; he died early \\
\hline Panayiotopulos G (19) & $\begin{array}{c}1.50 \\
19\end{array}$ & $\begin{array}{c}1.42 \\
14\end{array}$ & $\begin{array}{c}1.80 \\
-\end{array}$ & $8 \mathrm{t}$ \\
\hline $\begin{array}{l}\text { Goulandris N J (20)- } \\
\text { Lon. Based; traditional }\end{array}$ & $\begin{array}{c}1.52 \\
20\end{array}$ & $\begin{array}{c}1.40 \\
17\end{array}$ & $\begin{array}{c}1.20 \\
-\end{array}$ & From Andros; $10 \mathrm{~b} \mathrm{c}$ \\
\hline $\begin{array}{c}\text { Karnessis- }(21) \\
\text { Spyros \& Proc. }- \text { non traditional }\end{array}$ & $\begin{array}{c}1.36 \\
24\end{array}$ & $\begin{array}{c}1.26 \\
23\end{array}$ & $\begin{array}{c}2.00 \\
-\end{array}$ & From Megara -near Athens; European Nav.; $12 \mathrm{t}$ \\
\hline Lygnos Bros (Panayiotis \& John) (22) & $\begin{array}{c}1.18 \\
33\end{array}$ & $\begin{array}{c}1.25 \\
34\end{array}$ & $\begin{array}{c}1.80 \\
-\end{array}$ & From Chios; 34 b c in 1993 \\
\hline Frangos/Moundreas (23) & $\begin{array}{c}1.47 \\
42\end{array}$ & $\begin{array}{c}1.14 \\
36\end{array}$ & $\begin{array}{c}1.95 \\
-\end{array}$ & $\begin{array}{l}\text { Good Faith; Capital World Holds; start-off trend; } 20 \\
\text { G C }\end{array}$ \\
\hline Martinos Ath. (24) - non traditional & $\begin{array}{c}1.65 \\
30\end{array}$ & $\begin{array}{c}1.12 \\
20\end{array}$ & $\begin{array}{c}1.87 \\
-\end{array}$ & Split-off from Thenamaris; renewal policy; $13 \mathrm{~b} \mathrm{c}$ \\
\hline Niarchos (25) & $\begin{array}{c}1.36 \\
22\end{array}$ & $\begin{array}{c}1.09 \\
24\end{array}$ & $\begin{array}{c}1.30 \\
-\end{array}$ & New-building program; renewal policy; 12 b c sold \\
\hline $\begin{array}{l}\text { Chandris Bros (Group) - New- } \\
\text { Antonis \& Mimis (26) }\end{array}$ & $\begin{array}{l}1.00 \\
25\end{array}$ & $\begin{array}{c}1.03 \\
20 \\
\text { up }\end{array}$ & $\begin{array}{c}1.00 \\
-\end{array}$ & $\begin{array}{l}\text { From Chios; } 11 \text { t; run by Mimis' sons Jonh \& } \\
\text { Michalis; in Cruises too; Antonis passed away early }\end{array}$ \\
\hline Callimanopulos (27) & $\begin{array}{c}1.27 \\
19\end{array}$ & $\begin{array}{c}1.00 \\
16\end{array}$ & Dropped-down & Reducing; $13 \mathrm{~b} \mathrm{c}$ \\
\hline Eletson (28)-up-new & - & - & 1.03 & \\
\hline Petrakis (29)-up-new & - & - & 1.40 & \\
\hline Eonomou (30)-up-new & - & - & 1.20 & \\
\hline $\begin{array}{l}\text { Kollakis Bros (P \& G) - } \\
\text { new-(31)-up }\end{array}$ & - & Down & 2.30 & \\
\hline Total 31 companies & $\begin{array}{l}55 \mathrm{~m} \text { dwt; } \\
915 \text { ships }\end{array}$ & $\begin{array}{l}60 \mathrm{~m} \mathrm{dwt} \\
895 \text { ships }\end{array}$ & $70 \mathrm{~m} \mathrm{dwt}$ & Economies of scale \\
\hline
\end{tabular}

Source: Naftiliaki journal, various editions. $\left({ }^{*}\right)$ Certain figures are close to real. $\left.{ }^{* *}\right)$ Thenamaris is a strong example of the way shipping companies create one another. Athanasios established his own company: Eastern. ${ }^{* * *}$ ) From Piraeus. Kristen Nav. managed by “Astro Tankers". (\#) Dimitris is prepared to start-off its own company. (NB) "Adriatic Tankers" grew at an astonishing rate from 2 small product carriers in 1978 to over 100 by 1996 ! Couper et al. (1999: p. 72) accused the easy way that shipping finance can be obtained. Company faced difficulties in 1993, and due to unpaid debts, more than 67 ships were arrested. $\mathrm{GC}=$ general cargo; $\mathrm{t}=$ tankers; $\mathrm{b} \mathrm{c}=$ bulk carriers; pass. = passengers.

Nine shipowners emerged reaching up the leading ones: Zissimatos; Procopiou; Manios; Panayiotopulos; Karnessis; Lygnos; Frangos/Moundreas; Chandris \& Martinos Ath. Five shipowners dropped from the 1988 list: Tavulareas; Kollakis; Mavracakis; Hadjipateras \& Pegasus. In 1994, Greek-owned shipping had 3000 large ships valued $\$ 44 \mathrm{~b}, 16 \%$ of the global fleet and $3^{\text {rd }}$ in the world fleet, followed by Japan and Cyprus.

\section{Part VI: The 2004 Year}

As shown in Figure 11, in 2004, 46 shipping companies became leaders from 30 in 1995; with $94 \mathrm{~m}$ dwt and 1163 ships, against $70 \mathrm{~m}$ in 1995. 


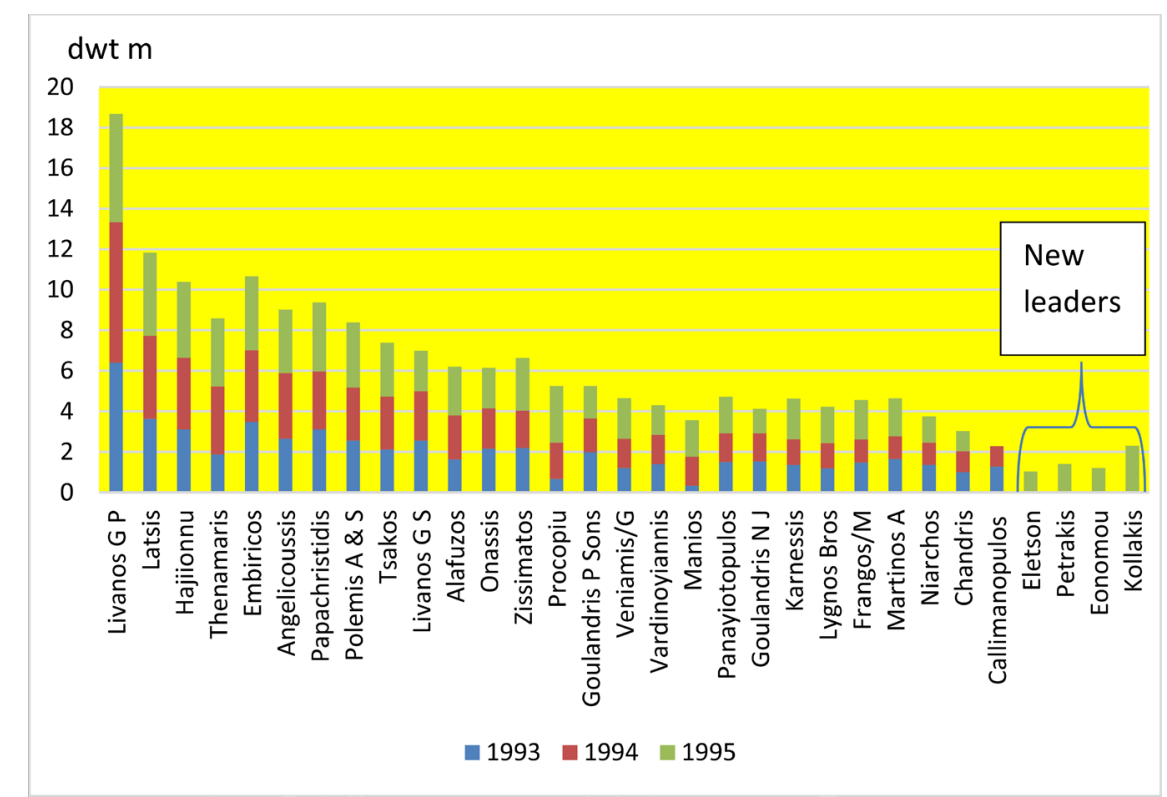

Source: Data from Naftiliaki Journal, Summer 1993-1995.

Figure 11. The 30 leading shipping companies plus Callimanapulos, 1993-1995.

Table 6. The 46 leading Greek-owned shipping companies in 2004 (June).

\begin{tabular}{|c|c|c|c|c|c|c|c|}
\hline Company & Dwt m & Ships Nos & Remarks & Company & Dwt & Ships Nos & Remarks \\
\hline $\begin{array}{l}\text { "Kristen"38 (1)—new- } \\
\text { (Hatzigrigoris-manager) }\end{array}$ & 5.92 & 27 & $\begin{array}{l}\text { Tankers; Agelef: } \\
\text { chartering }\end{array}$ & Chandris (24) & 2.05 & 19 & $12 \mathrm{t} ; 7 \mathrm{bc}$ \\
\hline Tsakos (2)-Ten & 5.75 & 53 & $\begin{array}{l}42 \mathrm{t} \\
8 \mathrm{CS}\end{array}$ & Embiricos (25) & 2.01 & 8 & $7 \mathrm{t}$ \\
\hline Georgiopulos P (3)-new & 5.45 & 44 & $\begin{array}{l}35 \mathrm{t} \\
9 \mathrm{OBO}\end{array}$ & Carras (26)-new & 1.91 & 12 & $\mathrm{~B} \mathrm{c}$ \\
\hline Prokopiou George (4) & 5.09 & 30 & $\begin{array}{l}26 \mathrm{t} \\
4 \mathrm{PT}\end{array}$ & Danaos/Coustas (27)—new & 1.86 & 31 & 24 cont.; 7 b c \\
\hline Martinos Const. (5) - Thenamaris & 3.53 & 47 & 19 t; 18 bc; 10 PT & $\begin{array}{l}\text { Kanellakis (28)- } \\
\text { new-Alpha tankers }\end{array}$ & 1.82 & 16 & $\mathrm{bc}$ \\
\hline Haji-ioannu Polys (6)—son & 3.43 & 29 & $\begin{array}{l}24 \mathrm{t} \\
4 \mathrm{PT}\end{array}$ & Angelopulos Th. (29)—new & 1.73 & 9 & $5 \mathrm{t} ; 2 \mathrm{PT}$ \\
\hline Martinos Ath. (7)-Eastern & 3.40 & 36 & $\begin{array}{c}22 \mathrm{bc} ; \\
14 \mathrm{t}\end{array}$ & Eletson (30) & 1.70 & 26 & $\mathrm{PT}$ \\
\hline Polemis A \& S (8) — Polembros & 3.34 & 30 & $\begin{array}{l}18 \mathrm{t} \\
10 \mathrm{bc}\end{array}$ & Kollakis (31)_Chartworld & 1.67 & 39 & $20 \mathrm{RF} ; 10 \mathrm{~b} \mathrm{c}$ \\
\hline Livanos G P (9) & 3.02 & 41 & $\begin{array}{l}20 \text { chem.; } 2 \text { OOC; } \\
3 \text { LNG; } 10 \mathrm{t}\end{array}$ & Cyprus Mar. (32)—new & 1.67 & 26 & $24 \mathrm{~b} \mathrm{c}$ \\
\hline Lykiardopulos (10)—new-Neda & 2.94 & 21 & $\begin{array}{l}13 \mathrm{~b} \mathrm{c} \\
4 \mathrm{PT}\end{array}$ & Papadimitriou (33) - new & 1.63 & 25 & $18 \mathrm{t}$ \\
\hline Economou G (11)—Cardiff/TMS & 2.82 & 26 & 9 bc; 1 OBO; 9 PT & Prokopiu D (34)-new & 1.61 & 18 & $18 \mathrm{t}$ \\
\hline $\begin{array}{c}\text { Mylonas (12)_new-Transmed } \\
\text { Cyprus }\end{array}$ & 2.77 & 21 & $20 \mathrm{bc}$ & Karnessis Bros (35) & 1.58 & 18 & $13 \mathrm{t} ; 5 \mathrm{bc}$ \\
\hline
\end{tabular}

${ }^{38}$ Kristen Navigation (in 1992) has the management of the tanker fleets of John Angelicoussis and the Kanellakis family, husband of Anna Angelicoussis. 


\section{Continued}

\begin{tabular}{|c|c|c|c|c|c|c|c|}
\hline Restis (13)-new & 2.69 & 33 & $\begin{array}{l}22 \mathrm{bc} \\
10 \mathrm{RF}\end{array}$ & Livanos G S (36) & 1.53 & 14 & $7 \mathrm{t} ; 7 \mathrm{PT}$ \\
\hline Vafias N \& H (14)-return & 2.65 & 22 & $14 \mathrm{~b} \mathrm{c}$ & Moundreas N (37) - new & 1.51 & 21 & $17 \mathrm{~b} \mathrm{c}$ \\
\hline Onassis (15) & 2.58 & 18 & $\begin{array}{l}12 \mathrm{t} \\
6 \mathrm{~b} \mathrm{c}\end{array}$ & Angelopulos C (38)-new & 1.50 & 15 & $6 \mathrm{t} ; 5 \mathrm{~b} \mathrm{c} ; 4 \mathrm{PT}$ \\
\hline $\begin{array}{c}\text { Diamantidis (16) — new } \\
\text {-Marmaras }\end{array}$ & 2.57 & 41 & B c & $\begin{array}{c}\text { Marinakis } \\
(39)-\text { new-“Barclay" }\end{array}$ & 1.49 & 28 & 13 chemicals \\
\hline Veniamis/Gabriel (17) & 2.50 & 27 & B c & Goulandris N J (40) & 1.46 & 14 & $8 \mathrm{~b} \mathrm{c} ; 6 \mathrm{t}$ \\
\hline Gulf Mar. (18)-new & 2.37 & 8 & $\mathrm{t}$ & Lemos N S (41)-new & 1.39 & 7 & $\mathrm{t}$ \\
\hline Angelicoussis (19)-Anangel & 2.30 & 24 & $\begin{array}{c}22 \text { b c; entry into } \\
\text { LNG (with } \$ 450 \mathrm{~m} \text { ) }\end{array}$ & Prime (42)-new & 1.36 & 22 & $12 \mathrm{t} ; 7 \mathrm{PT}$ \\
\hline Alafuzos (21) & 2.06 & 15 & $\mathrm{t}$ & Vardinoyiannis (44) & 1.17 & 54 & $34 \mathrm{t}$ \\
\hline Stelmar (22)-new & 2.06 & 36 & $\mathrm{t}$ & Stafilopatis (45)-new & 1.03 & 17 & $8 \mathrm{t} ; 8 \mathrm{~b} \mathrm{c}$ \\
\hline $\begin{array}{l}\text { Martinos And. } \\
\text { (23)-new-Minerva }\end{array}$ & 2.06 & 21 & $\mathrm{t}$ & $\begin{array}{c}\text { Mouscas } \\
\text {-new }\end{array}$ & 1.01 & 6 & B c \\
\hline Sub-total 23 companies & $\begin{array}{c}73.43 \mathrm{~m} \\
\mathrm{dwt}\end{array}$ & & & Total 46 companies & $\begin{array}{l}109.31 \\
\mathrm{~m} \mathrm{dwt}\end{array}$ & 1163 ships & 94.000 av. size \\
\hline
\end{tabular}

Source: Naftiliaki Journal, Summer 2004. CS = containerships; PT = product tankers; OOC = oil ore carriers; RF-reefers; $\mathrm{t}=$ tankers; $\mathrm{b} / \mathrm{b} \mathrm{c}=\mathrm{bulk}$ carriers To compile this table a lot of effort is required as companies change frequently name!

Eleven shipping companies dropped-down from the leaders (since 1995): Latsis; Papachristidis; Zissimatos; Goulandris P \& Sons; Onassis; Panayiotopulos; Lygnos; Frangos/Moundreas; Niarchos; Callimanopulos and Petrakis. But, 26 (!), marked new in Table 6, emerged: Vafias (returned): Procopiou D left his brother G. Martinos Andreas, left his brother C or D. Moundreas left Frangos. Seven companies ordered ULCCs ${ }^{39}$. These will help Greek-owned fleet to increase faster. This was a great leap forward!

The year 2004 is characterized as one when the Greek-owned fleet became younger and larger, with larger ships, and international with over... 51 flags (and $18 \%$ of world fleet)! The fleet increased from $172 \mathrm{~m}$ dwt to $180 \mathrm{~m}$ in 12 months. 2004 showed also the effect of the measures taken due to Erika/Prestige incidents.

Greek flag retained at $62 \mathrm{~m}$ dwt out of $180 \mathrm{~m}(1 / 3)$. Malta gained $31 \mathrm{~m}$; Panama $23 \mathrm{~m}$; Cyprus $23 \mathrm{~m}$; Bahamas $9 \mathrm{~m}$; Liberia $\sim 12 \mathrm{~m}$; Marshall Islands $\sim 7 \mathrm{~m}$. The average age in oil tankers was 8.4 years; in chemical \& products 10.2; pure containerships 12.6; ore \& bulk 14.5. Dry cargo, liquid gas and combination carriers need renewal (20 year; 17; 21 years respectively). Ships counted are over $1000 \mathrm{GT}(>1650 \mathrm{dwt})$.

\section{Part VII: The 2009-2018 Period}

This period is summarized in Table 7.

\footnotetext{
${ }^{39}$ Aeolos 320,000; Dorian 318,000; Gulf Mar. 306,000; Kristen 320,000; Lemos N S 318,000 \& 320,000; Martinos Ath. 308,000; and Martinos D. 318,700.
} 
Table 7. The 52 leading Greek-owned shipping companies, end 2009.

\begin{tabular}{|c|c|c|c|c|c|}
\hline Company & $\begin{array}{l}\text { Dwt m, number of } \\
\text { ships, Dec. } 2009 \\
\text { (rounded) }\end{array}$ & Company & $\begin{array}{l}\text { Dwt m, number of } \\
\text { ships, end } 2009 \\
\text { (rounded) }\end{array}$ & Company & $\begin{array}{l}\text { Dwt m, number of } \\
\text { ships, end } 2009 \\
\text { (rounded) }\end{array}$ \\
\hline Anangel & $14.2 ; 73$ & Euronav & $2.47 ; 16$ & Golden U. & $1.48 ; 16$ \\
\hline Cardiff & $10.4 ; 93$ & Navios & $2.39 ; 29$ & Vafias & $1.46 ; 56$ \\
\hline Tsakos & $7.4 ; 75$ & Centrofin & $2.34 ; 20$ & Andriaki & $1.45 ; 11$ \\
\hline Dynacom & $6.5 ; 45$ & Diana & $2.19 ; 20$ & Dioryx & $1.42 ; 18$ \\
\hline Enterprises & $5.2 ; 66$ & Danaos & $2.16 ; 42$ & Hellespond & $1.39 ; 22$ \\
\hline Marmaras & $4.5 ; 40$ & Arcadia & $2.16 ; 20$ & Capital & $1.33 ; 25$ \\
\hline Minerva & $4.5 ; 39$ & Costamare & $2.12 ; 27$ & Carras & $1.32 ; 10$ \\
\hline Gulf & $4.5 ; 17$ & Aries/Stamford & $2.04 ; 28$ & OSG Gr & $1.31 ; 24$ \\
\hline Thenamaris & $4.0 ; 39$ & Sun & $1.82 ; 17$ & Prime & $1.29 ; 18$ \\
\hline Maryville & $3.9 ; 49$ & Unisea & $1.81 ; 13$ & Metrostar & $1.27 ; 5$ \\
\hline Polembros & $3.7 ; 24$ & Eletson & $1.76 ; 28$ & Enesel & $1.18 ; 5$ \\
\hline Neda & $3.5 ; 22$ & Aeolos & $1.72 ; 7$ & Goldenport & $1.17 ; 23$ \\
\hline Chandris & $3.4 ; 23$ & Avin & $1.72 ; 22$ & Safety M & $1.15 ; 14$ \\
\hline Polyar & $2.9 ; 31$ & Samos & $1.7 ; 15$ & Star B & $1.09 ; 12$ \\
\hline Eastern & $2.9 ; 26$ & Cyprus & $1.59 ; 23$ & Good Faith & $1.09 ; 16$ \\
\hline Onassis & $2.6 ; 17$ & Chartworld & $1.53 ; 42$ & European N & $1.05 ; 14$ \\
\hline Alpha & $2.5 ; 20$ & Nereus & $1.5 ; 8$ & Marine M & $1.04 ; 8$ \\
\hline \multirow[t]{2}{*}{$\begin{array}{c}17 \text { large companies } \\
\rightarrow\end{array}$} & $\sim 87 \mathrm{~m} ; 699$ ships & 17 (middle) companies $\rightarrow$ & 33 m; 377 ships & $\begin{array}{c}\text { Byzantine } \\
18 \text { small companies } \rightarrow\end{array}$ & $\begin{array}{c}1.03 ; 16 \\
22.5 \mathrm{~m} ; 313 \text { ships }\end{array}$ \\
\hline & & & & $\begin{array}{c}\text { Grand total; } 52 \\
\text { companies }\end{array}$ & $\begin{array}{l}\sim 142 \text { m dwt; } 1389 \\
\text { ships; Av. 102,333 }\end{array}$ \\
\hline
\end{tabular}

Source: Data from MIS.

As shown, the tonnage owned by the 52 leading Greeks, increased from $109 \mathrm{~m}$ dwt in 2004 to $142 \mathrm{~m}$ (+30\%) in 2009, and from 1163 ships to 1389. Moreover, 6 companies climbed-up at the top. The 2009 is a year of the GFC. Economies of scale are also noted-from 94,000 dwt (2004) to $\sim 102,000$ (average size in 2009), being a competitive advantage.

In 2016, as shown in Table 8, 25 additional companies became leaders, since 2009. Making a total of 77 companies owning $301.5 \mathrm{~m} \mathrm{dwt}$ from $142 \mathrm{~m} \mathrm{dwt}$ (more than double); the 1389 ships became 2971! This was a great leap forward.

\section{Part VIII: The Angelicoussis Family-Case Study}

\subsection{History}

The Angelicoussis family created by Anthony A.- - a radio operator; having a profession for which his wife Maria was not proud of, and she was pressing him to become a shipowner. She was a Papalios nee, (a ship-owning family), and her 
Table 8. The 77 leading Greek-owned shipping companies, 2016.

\begin{tabular}{|c|c|c|c|c|c|}
\hline Company & $\begin{array}{l}\text { Dwt m, number of } \\
\text { ships, } 2016 \\
\text { (rounded) }\end{array}$ & Company & $\begin{array}{l}\text { Dwt m, number of } \\
\text { ships, } 2016 \\
\text { (rounded) }\end{array}$ & Company & $\begin{array}{c}\text { Dwt m, number of } \\
\text { ships, } 2016 \\
\text { (rounded) }\end{array}$ \\
\hline Anangel & $\begin{array}{c}22.30 \\
115\end{array}$ & Technomar & $\begin{array}{c}3.52 \\
59\end{array}$ & Target & $\begin{array}{c}1.67 \\
21\end{array}$ \\
\hline Euronav & $\begin{array}{c}16.80 \\
95\end{array}$ & Safety-Safe B & $\begin{array}{c}3.49 \\
39\end{array}$ & Nereus & $\begin{array}{c}1.66 \\
11\end{array}$ \\
\hline Navios & $\begin{array}{l}14.55 \\
142\end{array}$ & Cyprus & $\begin{array}{c}3.36 \\
37\end{array}$ & Kyklades & $\begin{array}{c}1.65 \\
13\end{array}$ \\
\hline Dynacom & $\begin{array}{c}13.18 \\
104\end{array}$ & Moundreas & $\begin{array}{c}3.28 \\
29\end{array}$ & Hellespont & $\begin{array}{c}1.61 \\
14\end{array}$ \\
\hline Cardiff & $\begin{array}{l}12.99 \\
109\end{array}$ & Optimum & $\begin{array}{c}3.24 \\
45\end{array}$ & V. Ships Gr & $\begin{array}{l}1.56 \\
29\end{array}$ \\
\hline Gener8 & $\begin{array}{c}9.38 \\
40\end{array}$ & Empire-Alma & $\begin{array}{c}3.23 \\
40\end{array}$ & Sea World & $\begin{array}{l}1.54 \\
29\end{array}$ \\
\hline Star Bulk/Product & $\begin{array}{c}8.60 \\
92\end{array}$ & Enterprises-Golden En. & $\begin{array}{c}3.22 \\
37\end{array}$ & Seanergy & $\begin{array}{c}1.50 \\
10\end{array}$ \\
\hline $\begin{array}{l}\text { Alpha/Amethyst/Pantheon/ } \\
\text { Angelicoussis Anna }\end{array}$ & $\begin{array}{c}8.10 \\
48\end{array}$ & Arcadia & $\begin{array}{c}3.12 ; \\
30\end{array}$ & Consolidated & $\begin{array}{c}1.50 \\
23\end{array}$ \\
\hline Tsakos & $\begin{array}{c}7.90 \\
81\end{array}$ & Chartworld & $\begin{array}{c}2.94 \\
64\end{array}$ & Dorian & $\begin{array}{l}1.42 \\
24\end{array}$ \\
\hline $\begin{array}{l}\text { Thenamaris/ } \\
\text { N \& D Martinos }\end{array}$ & $\begin{array}{c}7.42 \\
74\end{array}$ & Enesel & $\begin{array}{c}2.89 \\
18\end{array}$ & Iolcos & $\begin{array}{c}1.39 \\
17\end{array}$ \\
\hline Minerva & $\begin{array}{c}7.32 \\
63\end{array}$ & Transmed & $\begin{array}{c}2.75 \\
21\end{array}$ & Eurotankers & $\begin{array}{c}1.35 \\
13\end{array}$ \\
\hline Marmaras & $\begin{array}{c}7.31 \\
52\end{array}$ & Vafias & $\begin{array}{c}2.63 \\
83\end{array}$ & Eurobulk & $\begin{array}{c}1.35 \\
30\end{array}$ \\
\hline Diana/Palios & $\begin{array}{c}6.42 \\
60\end{array}$ & Nomikos A M & $\begin{array}{c}2.53 \\
42\end{array}$ & European & $\begin{array}{c}1.32 \\
22\end{array}$ \\
\hline New Sh. & $\begin{array}{c}6.13 \\
35\end{array}$ & Samos & $\begin{array}{c}2.50 \\
24\end{array}$ & Altomare & $\begin{array}{c}1.30 \\
10\end{array}$ \\
\hline Eastern/Ath. Martinos & $\begin{array}{c}6.00 \\
65\end{array}$ & Avin & $\begin{array}{c}2.33 \\
37\end{array}$ & Gleamray & $\begin{array}{c}1.20 \\
14\end{array}$ \\
\hline Capital & $\begin{array}{c}5.75 \\
60\end{array}$ & Almi & $\begin{array}{c}2.26 \\
13\end{array}$ & Polyar & $\begin{array}{c}1.17 \\
20\end{array}$ \\
\hline Onassis & $\begin{array}{c}5.27 \\
27\end{array}$ & Marine Mangt. & $\begin{array}{c}2.16 \\
20\end{array}$ & Atlas & $\begin{array}{c}1.15 \\
8\end{array}$ \\
\hline Golden Union & $\begin{array}{c}5.20 \\
40\end{array}$ & Prime & $\begin{array}{c}2.11 \\
31\end{array}$ & Atlantic & $\begin{array}{c}1.14 \\
19\end{array}$ \\
\hline Costamare & $\begin{array}{c}4.90 \\
65\end{array}$ & Lomar & $\begin{array}{c}2.04 \\
65\end{array}$ & Navarone & $\begin{array}{c}1.14 \\
34\end{array}$ \\
\hline Danaos/Coustas & $\begin{array}{c}4.20 \\
59\end{array}$ & Andriaki/Goulandris N J & $\begin{array}{c}2.02 \\
15\end{array}$ & Alkyon & $\begin{array}{c}1.13 \\
7\end{array}$ \\
\hline Chandris & $\begin{array}{c}3.97 \\
30\end{array}$ & Sun & $\begin{array}{c}1.96 \\
22\end{array}$ & Stamco & $\begin{array}{c}1.07 \\
59\end{array}$ \\
\hline Centrofin/Procopiou D & $\begin{array}{c}3.94 \\
27\end{array}$ & Goldenport & $\begin{array}{c}1.92 \\
39\end{array}$ & Carras & $\begin{array}{c}1.07 \\
9\end{array}$ \\
\hline
\end{tabular}




\section{Continued}

\begin{tabular}{|c|c|c|c|c|c|}
\hline Neda/Lyciardopulos & $\begin{array}{c}3.80 \\
23\end{array}$ & Athenian C & $\begin{array}{c}1.91 \\
6\end{array}$ & Phoenix & $\begin{array}{c}1.06 \\
8\end{array}$ \\
\hline Laskaridis & $\begin{array}{c}3.77 \\
72\end{array}$ & Eletson & $\begin{array}{c}1.77 \\
33\end{array}$ & $\mathrm{ADK}$ & $\begin{array}{c}1.03 \\
10\end{array}$ \\
\hline Aeolos/ Empiricos & $\begin{array}{c}3.72 \\
27\end{array}$ & Quintana & $\begin{array}{c}1.76 \\
14\end{array}$ & $\begin{array}{l}\text { Polembros/ } \\
\text { Polemis }\end{array}$ & $\begin{array}{c}3.59 \\
21\end{array}$ \\
\hline Byzantine & $\begin{array}{c}1.67 \\
28\end{array}$ & & & & \\
\hline \multirow[t]{2}{*}{$\begin{array}{c}\text { Sub-total } 26 \text { large } \\
\text { companies } \rightarrow\end{array}$} & $\begin{array}{c}202.5 \mathrm{~m} \mathrm{dwt} ; 1626 \\
\text { ships; } 124,539 \text { av. size }\end{array}$ & $\begin{array}{l}\text { Sub-total } 26 \text { middle } \\
\text { companies } \rightarrow\end{array}$ & $\begin{array}{l}67 \text { m dwt; } 891 \text { ships; } \\
\text { 75,196 av. size }\end{array}$ & $\begin{array}{l}\text { Sub-total } 25 \text { small } \\
\text { companies } \rightarrow\end{array}$ & $\begin{array}{c}32 \text { m dwt; } 454 \text { ships; } \\
70,485 \text { av. size }\end{array}$ \\
\hline & & & & $\begin{array}{c}\text { Total } 77 \\
\text { companies } \rightarrow\end{array}$ & $\begin{array}{l}301.5 \mathrm{~m} \text { dwt; } 2971 \\
\text { ships; } 101,481 \mathrm{dwt} \\
\text { average size }\end{array}$ \\
\hline
\end{tabular}

Source: as Table 7.

brother was a shipowner. A was born in Kardamyli in S Peloponnesus (Mani), and in 1870-80 changed his surname to present. Due to Piracy, the family moved to $\mathrm{N}$ Chios in 1850, and gave there the name Kardamyla, after its original village. The family returned to its original home, due to 1821 revolution and the 1822 Chian massacre, till 1857, when they returned to Chios.

\subsection{Anthony as a Shipowner (1918-1989)}

Anthony started a shipping company with friends, and small ships, as common among Greeks. In early 1960-1970, A bought certain Liberty ships. Thanks God, for Greek-owned shipping, partners-friends split-off.

A in 1987 impressed shipping community by a joint float with American Express Bank in NYSE for the first time in history. A established the company “Anangel American S L" (AASL) ${ }^{40}$, which survived 2 depressions in 1970-1990. A was absent in 1970, by dwt, among the 8 leaders. In 1976, A owned 28 ships of 761,000 dwt; by 1985 owned 48 ships of $1.33 \mathrm{~m} \mathrm{dwt}$; by 1988 owned $1.30 \mathrm{~m} \mathrm{dwt}$ against 0.98 in 1986 and from 43 ships he arrived at 47. In 1989 he passed away.

The characteristic of A was his total committed to new-buildings ${ }^{41}$, in Japan (IHI), in cooperation with them for over 18 continuous years, and for a certain range of tonnage! For Greeks this was a paradigm shift, being traditionally $2^{\text {nd }}$ handers! A specialized: in "Freedoms", "F" series (15,000 dwt), "Freedoms Mark II", "Fortunes" and "Friendships" (bulk carriers 22,500 dwt), providing trading

\footnotetext{
${ }^{40}$ AASL company grew out of an entrepreneurial association between "Angelicoussis ship holding group", "American Express bank" and "Lehman Bros". In end-1986 formed a joint venture company by the 1st 2 of the above, to buy 2 young bulk carriers. By $19873 \mathrm{~m}$ A shares at $\$ 10$ offered to public, $3 \mathrm{~m}$ for $>\$ 10$ and $1.5 \mathrm{~m}$ of $11 \%$ cumulative non-voting preferred shares at $\$ 10$. Angelicoussis subscribed for $3 \mathrm{~m} \mathrm{~B}$ ordinary shares at $\$ 9.5$ using a loan from AMEX for the $75 \%$ of this. AASL followed a no-debt policy. All vessels bought were $<7$ years old!

${ }^{41}$ Greeks out of necessity, and strategy, used to enter into the shipping markets via $2^{\text {nd }}$ hand ones, where tonnage was older, cheaper and thus competitive in certain items of costs. With the exception of Onassis, Greek-owned shipping companies grew through past years' profits and thus it was slow and cyclical. Greek shipowners had also a number of cases where large loans, large ships, and low freight markets, brought-in bankruptcies (e.g., Colocotronis M). Apropos is a Greek saying: "the size of the quilt you have is going to determine what part of your feet will be not covered". This is what I say to my students: "estimate the freight market when a newbuilding will be delivered, i.e., in 2 - 3 years ahead" not when one places the order! Also, estimate how supply is going to increase by the orders of all other shipowners including your own.
} 
flexibility able to survive during a shipping crisis, because a minimum volume of seaborne trade has to be served...

\subsection{John and Anna as Shipowners (1949-)}

John and Anna took over after A's death. In early 1990s company moved into Capes, VLCCs and Suezmaxes. It took 11 years after their father's death, in 2000, for John and Anna to split off -for the great benefit of Greek-owned shipping! John learned shipping business from his father, since 1974, as this was common among Greeks. Maria took-over by herself in April 2021 after John's death.

In 2001, "Anangel ASL" turned private, and John left the Stock Exchange, perhaps forever... He did not regret it. In 2004 entered into LNGs, having 30 units by 2018. Thanks God again, in 2008 Maria-his daughter-took over jointly ... and though 2 Greeks, they agreed to everything...In 2018 "Anangel" owned 102 ships ( $24.5 \mathrm{~m} \mathrm{dwt}$ ) and soon it will reach 131. Family's whereabouts are presented in Table 9.

Table 9. The Angelicoussis ship owning family, 2018.

\begin{tabular}{|c|c|c|c|}
\hline Christian Name & Lived/established & Founder of & Remarks \\
\hline Antonis $\rightarrow$ & 1918-1989 & He bought his $1^{\text {st }}$ vessel “Astypalea” (1950) & $\begin{array}{l}\text { Radio officer; Agent of Papalios N } \\
\text { in Piraeus }\end{array}$ \\
\hline $\begin{array}{l}\text { Antonis } \rightarrow \text { established the } \\
\text { following companies: } \rightarrow\end{array}$ & $1950 \rightarrow$ & The “Angelicoussis A \& Efthymiou D” Co. & $\begin{array}{l}\text { Made-up by: A + Efthymiou D + } \\
\text { Kaloudis P }\end{array}$ \\
\hline Also $\rightarrow$ & Early 1960s-1968 $\rightarrow$ & "Pegasus Ocean Services" (London) & $\begin{array}{l}\text { In partnership with the families of: } \\
\text { Peraticos, Xylas, Andrianopulos \& } \\
\text { Inglessis; all created their own } \\
\text { companies }\end{array}$ \\
\hline Also $\rightarrow$ & $1968-1971 \rightarrow$ & “Agelef” (London) & +D Efthymiou \\
\hline Also $\rightarrow$ & $1972 \rightarrow$ & “Anangel Shipping Enterprises S.A.” & $\begin{array}{l}+\mathrm{G} \text { M Pateras, who up to } 1985 \text { was } \\
\text { a minor shareholder establishing } \\
\text { then his own company: "Common } \\
\text { Progress SA" } 42\end{array}$ \\
\hline Antonis $1965-1985 \rightarrow$ & $\begin{array}{l}\text { Built } 42 \text { ships in the Japanese } \\
\text { yard IHI, } 15,000-22,500 \mathrm{dwt}\end{array}$ & & Average fleet age 7 years (1975) \\
\hline $\begin{array}{l}\text { Antonis } \rightarrow \\
\text { Passed away in } 1989 \\
\text { The Children of Antonis } \\
\text { took over in } 1989\end{array}$ & $\begin{array}{l}\text { 1987; in cooperation with } \\
\text { American Express Bank } \rightarrow\end{array}$ & "Anangel American Ship-holdings Ltd" & $\begin{array}{l}\text { Listed in Stock exchanges of NY } \\
\text { (NASDAQ) \& Luxembourg S E } \\
\text { The “Anangel Shipping } \\
\text { Enterprises" company }\end{array}$ \\
\hline $\begin{array}{l}\text { John, } 1989-2021 \text {; in } 2015 \text { he } \\
\text { got the } 1^{\text {st }} \text { position among } \\
72 \text { Greek shipowners, with } \\
\sim 21 \mathrm{~m} \text { dwt, \& } 105 \text { vessels; he } \\
\text { added } 2.15 \mathrm{~m} \text { dwt by } 2015 \\
\text { with occasional visits to } 2^{\text {nd }} \\
\text { hand markets }\end{array}$ & $\begin{array}{l}2000 \text { split off from Anna, his } \\
\text { sister; } 2001 \text { company's structure } \\
\text { changed; in } 2002 \text { he bought the } \\
\text { shares of "Anangel American } \\
\text { Shipholding Ltd" }\end{array}$ & $\begin{array}{l}\text { Using new buildings in tankers \& dry } \\
\text { cargoes; his fleet consisted of } 36 \text { tankers, } 51 \\
\text { bulk carriers and } 18 \text { LNGs... In } 2018, \\
\text { "Anangel-Maran Tankers/Gas" owned } 127 \\
\text { ships of } 24.5 \mathrm{~m} \text { dwt; the company "Maran } \\
\text { Gas" took-over the "Maran Nakilat"-the } \\
\text { shipping arm for the world's largest LNG } \\
\text { producer-"Qatargas"-with a profit of } ~ \$ 66 \\
\text { m ( } 8 \% \text { up to the profit share in the } \\
11 \text {-year-old “joint venture" ( } 13 \text { LNGs). }\end{array}$ & $\begin{array}{l}\text { Used Greek flag \& time charters; } \\
\text { playing with assets; managed by } \\
\text { "Anangel Maritime Services Inc." } \\
\text { (dry cargoes) \& "Kristen } \\
\text { Navigation Inc." (tankers) }\end{array}$ \\
\hline
\end{tabular}

Source: author from various sources.

\footnotetext{
${ }^{42}$ Six ships in 2018 of 342,158 dwt.
} 
The reader must pay attention as to the number of partners involved in Angelicoussis' case-study, which gradually, and eventually, all established their separate shipping companies! The more people-Greeks-are involved in shipping owning and management, the more spins-off are about to be created! This is the way to create a great shipping belonging to Hellenes. "Strength is achieved by unity and progress is achieved by setting-off"!

The research so far has been concentrated in national fleets and the way they have grown over time. This paper started from the fact that a national fleet is made-up by a number of individual companies and by their way of adding ships and tonnage to their ownership. We showed the best practices adopted by Greek shipowners to create new companies and also to expand them by leaps and bounds, perhaps by setting-off, but not exclusively. This analysis may be useful to those managers who want to know the ways new companies are created or how existing companies have expanded so that to follow their example. This research has been facilitated by the availability of detailed data at companies' level, which we have nowadays even at a cost.

A further research may take-out the issues we raised one by one and provide a deeper research for each, like e.g., the role of tradition, the family culture, the trend to create a new company by each family number, the intermarriages and so on. This way we will see the trees that make-out the forest.

\section{Conclusion}

Stopford (2009) characterized shipping business wrongly as unattractive, while we admit it to be extremely cyclical. Greeks being shipowners by tradition, and having it as a way of life, are not anymore, the small, unimportant, ones, as used to be, pursuing all their opportunities in the $2^{\text {nd }}$ hand market. Neither shipping markets are purely competitive at times, where supply can influence price as it did in the past.

Maximizing profits cannot be taken for granted. Total cost must be minimized given prevailing freight rate. To this effect Greek state has helped shipping by providing reduced national crew requirements, by excluding a number of ratings and a number of Greek officers from being on board, except Captain...

Greek ship-owners were blessed by having large families, where the characteristic example is Petros Goulandris ${ }^{43}$. We underlined out the cases most frequently, among Greek shipowners, of "appointing" their children as their successors. In addition, most of the time, companies were formed with brothers, or many partners, which eventually were prone to set off. Moreover, intermarriages continued. The Greek mentality that where there are 2 Greeks, there are 4 different opinions, also helped to establish many new shipping companies!

\footnotetext{
${ }^{43}$ Traditional, from Andros, having 5 children: Basil, Nikos, John, George and Costas! We cannot support the opinion that large families were made on purpose to...create successors-shipowners, but the infant mortality perhaps played its role along with religious considerations and the fact that husbands stayed away from home for a number of months or years.
} 
Thus, families split-out/spin-off and are clearly behind the cause of the creation of the Modern Greek shipping miracle. As showed, the emerged companies reached a greater size than the original ones (example: the Martinos Brothers, who created 3 companies, owned $25 \mathrm{~m}$ dwt in 2018!). John Angelicoussis and Anna had together $34 \mathrm{~m} \mathrm{dwt} \mathrm{in} 2018$ ( $2^{\text {nd }}$ quarter). There is no need to mention Navios (Angeliki Frangou with $15 \mathrm{~m} \mathrm{dwt}$ ). Procopiou brothers created a number of separate companies (Centrofin and Dynacom $13.18 \mathrm{~m}$ ).

We showed also that the global depressions, either in tankers or in dry cargo ships, or the GFC, in end-2008, stalled indeed the growth rate of Greek-owned fleet. The GFC affected also the other 9 top world nations, but not all at the same time. Greece was unaffected between 2009 and 2018; Japan: 2007-2015; China: 2007-2014; Singapore: 2007-2014 and 3 others: 2014-2018. Among the 10 top nations 6 halted their growth between 2007 and 2012.

The expansion of the number of companies, we have showed, made greater also the fleet to which they belong to (the Greek-owned). In 2016, 200 Greek-owned shipping companies owned $356 \mathrm{~m}$ dwt of about 230,000 dwt and over each.

Certain 4 - 5 Greek-owned companies, however, were victims of their own policy, based on over-ambitious economies of scale (e.g., building, and especially ULCCs \& VLCCs)!

There was an argument that the 8 leading shipowners, who emerged in 1970, were also "helped" by the 7 oil-majors' policy, but when the latter decided to stop to be shipowners, Greek shipowners then exposed. It is also argued that the 11 companies, which emerged in 1985, were helped by the concessionary offshore legislation, originally enacted by the military dictatorship and confirmed by the National Government (formed in mid-1974), and protected also by the Greek constitution.

It was not only the set-off mechanisms responsible for creating a plethora of new leading Greek-owned shipping companies, but also the care of fathers to make their children-including daughters-future shipowners (Martinos C or D of Thenamaris created John with 5 ships; Nicholas ${ }^{44}$ took-over the Thenamaris itself-and married to Procopiou's daughter!).

Haji-Ioannou, L. in 1994, bought 3 tankers for his son Stelios (Stelmar), and he was long prepared, before his death in 1989, to withdraw, resting on his 3 children: Stelios, Clelia and Polys (latter's his Polyar company owned $1.17 \mathrm{~m} \mathrm{dwt}$ in 2018). Frangos has Angeliki, and he set off from Moundreas (3.28 m dwt for the latter). Tsakos has Nicos. Danaos has John. Vafias has Harry (2.63 m dwt). In Eletson (1.77 m dwt), which consisted of 5 ex-Captains, some of them have children. Costamare had Costas (4.9 m dwt). Latsis, too, appointed his son, and so on.

\footnotetext{
${ }^{44}$ Martinos (Easter) has 2 daughters. A fear related to daughters is the one related to dowry-hunters; Polemis set-off. Onassis left $1 / 2$ of his property to his daughter Christina, but she passed-away. Niarchos had 2 sons, where Phillipos took over. Callimanopoulos left a son (Gregory). Livanos G left a nephew. Chandris D left sons, as well the Goulandris families left children.
} 
Eleven shipping companies in 1985 grasped the opportunity among a crisis to reach the previous, finally 7 , big ones, and increased leading companies to 18 ! These owned from about $18 \mathrm{~m}$ in 1970 to $28 \mathrm{~m}$ in 1976 and $34.5 \mathrm{~m}$ in $1985^{45}$. A crisis thus was another cause for creating shipping companies...along with tradition.

We may gather together the factors that have created, or destroyed, an exceptional number of Greek-owned leading shipping companies since 1970:

Factor
Exploit depressions, because
they create great opportunities;
for this put funds aside or find
finance; apply perfect timing in
all kinds of decisions, starting
from the big ones (Goulielmos,
$2021 b$ )

Create large families (a la Petros Goulandris), no matter sex

Sky is the limit, but a fall from heavens is probable \& tragic; always remember: have a parachute or do not fly!

\section{Factor}

Tradition provides a confidence in copying one's ancestors, but with able discretion, as things change

\section{Factor}

The care of shipping fathers about their children so that to become shipowners: endowed with ships \& know-how! And if children and father are both in life, they have also his supervision till his death (e.g., Niarchos; Tsakos)

\section{Factor}

Greek shipowners-fathers engage their children in business with 10 commandments: 1 . Apply Economies of scale, but carefully; $2 \& 3$. Buy/build cheap (at rock-bottom prices); 4 \& 5. Apply economies of age and size (larger \& younger ships); 6 \& 7. Sell smaller \& older vessels; 8 . Disregard crises (win-win policy); 9-10 if you forgot the above 8 then in Shipping "do as Greeks do"

Families are prone to set-off when made-up by brothers, cousins, sisters, nephews etc.; partners are also prone to spin-off

Economies of scale is a good thing! Inexperienced banks or investors But is going to be there the proper may lend money, but a shipping demand?
Intermarriages create larger fleets Greeks never agree how to run a by shipowners being just in Church company; set-off is outside their door
Learn to reduce costs in line with the level of the prevailing freight rate; this is the "Economics of Shipping" in 3 words!

Source: author.

\section{Conflicts of Interest}

The author declares no conflicts of interest regarding the publication of this paper.

\section{References}

Archibald, G. C. (Ed.) (1971). The Theory of the Firm, Selected Readings. UK: Penguin Education.

Besanko, D., Dranove, D., Shanley, M., \& Schaefer, S. (2013). Economics of Strategy (6th ed.). Singapore: Wiley.

Couper, A. D. et al. (1999). Voyages of Abuse: Seafarers, Human Rights and International Shipping. London \& VA, USA: Pluto Press.

Goulielmos, A. M. (1997). The Factors Determining the Foreign Exchange Inflow from Shipping Companies in Greece: During the Deep and Prolonged Crisis, 1981-1987. Piraeus: Department of Maritime Studies, University of Piraeus.

Goulielmos, A. M. (1998). Flagging-Out and the Need for a New Greek Maritime Policy. Transport Policy, 5, 115-125. https://doi.org/10.1016/S0967-070X(98)00005-5

${ }^{45}$ To have a comparison, the 10 global largest shipping companies owned, in 1988, about $68 \mathrm{~m} \mathrm{dwt}$ including Shell, Mitsui, Chevron, Moller and NYK. This means that Greek shipping companies had $1 / 2$ the size of the international ones at that time. 
Goulielmos, A. M. (2000). A Proposed Shipping Policy to Counteract Flagging-Out: The Paradigm of Greece. Maritime Economics \& Logistics, 2, 27-47. https://doi.org/10.1057/ijme.2000.5

Goulielmos, A. M. (2018). The "Modern Greek Maritime Policy”, 1953-2018: A Critical Review of Its Legal, Economic and Institutional Framework. Modern Economy, 9, 1190-1212. https://doi.org/10.4236/me.2018.97078

Goulielmos, A. M. (2020a). Society in Front of 2 Enemies: COVID-19 \& Climate Collapse/Their Impact on Shipping Industry. Modern Economy, 11, 2006-2026. https://doi.org/10.4236/me.2020.1112134

Goulielmos, A. M. (2020b). The Investment Strategy and the Growth Policy of Greek Shipowners Revealed, 1946-2020. Modern Economy, 11, 1858-1886. https://doi.org/10.4236/me.2020.1111125

Goulielmos, A. M. (2021a). To Be or Not to Be Listed? A Dilemma of the Greek-Owned Cyclical Shipping Companies, 1993-2018. Modern Economy, 12, 401-428. https://doi.org/10.4236/me.2021.122021

Goulielmos, A. M. (2021b). Why the Perfect Timing Achieved by the Managers of Shipping Companies Is So Important? Modern Economy, 12, 597-622. https://doi.org/10.4236/me.2021.123031

Harlaftis, G. (1996). A History of Greek-Owned Shipping: The Making of an International Tramp Fleet, 1830 to the Present Day. London \& New York: Routledge.

Henderson, J. M., \& Quandt, R. E. (1958). Microeconomic Theory: A Mathematical Approach. New York: McGraw-Hill Book Co, Inc.

Keynes, J. M. (1936). The General Theory of Employment Interest and Money. London: MacMillan \& Co Ltd.

Robbins, S. P., \& Coulter, M. (with contributors) (2018). Management (14th ed.). London and New York: GE, Pearson.

Stokes, P. (1997). Ship Finance: Credit Expansion and the Boom-Bust Cycle (2nd ed.). Business of Shipping Series, London, Hong Kong: Lloyd's of London Press.

Stopford, M. (2009). Maritime Economics (3rd ed.). London \& New York: Routledge. https://doi.org/10.4324/9780203891742

Tenold, S. (2015). Geared for Growth: Christian Gerhard Jebsen and His Shipping Companies. Bergen: Bodoni.

Thanopulu, H. A. (1996). Anticyclical Investment Strategies in Shipping-The Greek Case. In D. Hensher et al. (Eds.), World Transport Research (Vol. 4, pp. 209-220) Oxford: Elsevier. 